HID 46 (2019)

\title{
COFRADAS Y DEVOTAS: EL PAPEL DE LA MUJER EN LAS COFRADÍAS PENITENCIALES EN LA SEVILLA DE LOS AUSTRIAS (1538-1701) ${ }^{1}$
}

\author{
COFRADAS AND DEVOTEES: THE ROLE OF WOMEN IN THE \\ PENITENTIAL CONFRATERNITIES IN SEVILLE IN THE REIGN OF \\ THE AUSTRIAS (1538-1701)
}

\author{
David Granado Hermosín \\ Universidad Pablo de Olavide \\ davidgranadohermosin@gmail.com ORCID: https://orcid.org/0000-0001-7477-7451
}

RESUMEN: En este trabajo queremos presentar el papel que tuvieron las mujeres dentro de las cofradías penitenciales de Sevilla durante el reinado de los Austrias. Lo haremos mediante el uso de dos fuentes fundamentales para estudiarlas: el archivo del Arzobispado de Sevilla y los archivos de las distintas cofradías actuales. Estos documentos reflejan plenamente cómo vivían, se organizaban y sentían las mujeres miembros de este gran colectivo dentro de la Iglesia católica. Por tanto, estudiar la religiosidad cofrade es también estudiar el sentir religioso de los laicos. Nos centraremos en cuatro aspectos fundamentales: sus calidades, recibimiento y cuotas de entrada, las cofradas (doncellas, viudas, religiosas, extranjeras y nobleza), las profesiones y las mujeres en el gobierno de las cofradías.

PALABRAS ClAVES: Religiosidad; cofradías; Trento; historia de la mujer; piedad popular.

Recibido: 20-2-2019; Aceptado: 4-6-2019; Versión definitiva: 7-6-2019.

1. Abreviaturas utilizadas: AAJNS $=$ Archivo de la Archicofradía de Jesús Nazareno de Sevi1la; AGAS = Archivo del Arzobispado de Sevilla; AHA = Archivo de la Hermandad de la Amargura; $\mathrm{AHCH}=$ Archivo de la Hermandad del Cachorro; AHCRR = Archivo de la Hermandad de la Carretería; AHEM = Archivo de la Hermandad de la Esperanza Macarena; AHGP = Archivo de la Hermandad del Gran Poder; AHM = Archivo de la Hermandad de Montserrat; AHN = Archivo de la Hermandad de los Negritos; $\mathrm{AHO}=$ Archivo de la Hermandad de la O; AHP = Archivo de la Hermandad del Prendimiento; AHQA = Archivo de la Hermandad de la Quinta Angustia; AHSL = Archivo de la Hermandad de la Sagrada Lanzada; AHSP = Archivo de la Hermandad de las Siete Palabras; AHT = Archivo de la Hermandad de la Trinidad; AHTCSI = Archivo de la Hermandad de las Tres Caídas de San Isidoro; $\mathrm{AHVC}=$ Archivo de la Hermandad de la Vera Cruz; APSNB $=$ Archivo de la Parroquia de San Nicolás de Bari.

Copyright: (C) Editorial Universidad de Sevilla. Este es un artículo de acceso abierto distribuido bajo los términos de la licencia de uso y distribución Creative Commons Reconocimiento-No-ComercialSinObraDerivada 4.0 (CC BY-NC-ND 4.0) 
ABSTRACT: In this paper we aim to show the role that women had in the penitential confraternities in Seville during the reign of the Habsburgs. In order to achieve our purpose we have used two fundamental sources: the archive of the Archbishopric of Seville and the archives of the different current confraternities. These associations were generally composed of laypersons, which means that their documents show how these people felt and lived. We have studied four different aspects: their qualities, reception and entrance fees, the cofradas (maidens, widows, religious, foreigners and nobility), the professions and women in the government of the fraternities.

KEYWORDS: Religiousness; confraternities; Trento; women's history; popular piety.

\section{INTRODUCCIÓN}

Ser mujer en la España del Antiguo Régimen, a decir de Soria, suponía, al igual que las anteriores épocas, una forma de discriminación. Si los individuos eran desiguales ante la ley, mucho más lo eran en función del género que pose$y_{e r a n^{2}}$. Esto ha ocasionado que la presencia femenina en la Historia haya pasado prácticamente desapercibida. La historiografía actual ha conseguido sacar a la luz la importancia que tuvieron las mujeres en la Historia, convirtiendo el género en un concepto clave para el análisis histórico ${ }^{3}$.

A pesar de que en los últimos años se ha escrito mucho sobre la Historia de las mujeres, poco es lo publicado acerca de su religiosidad ${ }^{4}$, especialmente la de los grupos populares ${ }^{5}$. La religiosidad se perfila como un rasgo esencial en la educación de las mujeres durante la época moderna ${ }^{6}$. En este referido ámbito religioso, campo de estudio para nuestra investigación, la profesora Pérez González, al tratar acerca del papel de las mujeres dentro de las cofradías andaluzas bajomedievales, expuso que

en la mayoría de las grandes religiones la mujer ha experimentado y experimenta un trato desigual en cuanto a sus derechos y su dignidad con respecto a los varones con los que comparte credo y prácticas religiosas ${ }^{7}$.

Así ocurrió en la Baja Edad Media y siguió ocurriendo entre los siglos XVI y XVII, cuando el papel de la mujer en la Iglesia católica estuvo relegado principalmente a la vida conventual, estando vedado a la mujer laica, no perteneciente a una orden religiosa, todo aquello que supusiera cercanía o familiaridad con lo

2. Soria Mesa 2003, p. 460.

3. Ibidem, p. 461.

4. Sobre las fuentes para estudiar la mujer véase Segura Graiño 1991.

5. Casquero Fernández 1997, p. 59.

6. Echániz Martínez 2012, p. 279.

7. Pérez González 2012, p. 185. 
sagrado $^{8}$, por lo que su presencia de forma activa en la vida parroquial es raro de encontrar.

Usando las palabras de Pérez González,

las mujeres y las cofradías mantuvieron distintos tipos de relaciones. Estos vínculos se manifiestan a través de diferentes ámbitos y se establecieron con la institución en general o con algunos de sus integrantes en particular 9 .

La gran variedad de estos vínculos la analizamos en este artículo, donde estudiamos el papel de la mujer en el seno de las cofradías penitenciales sevillanas, es decir, de aquellas que realizaron la procesión de penitencia durante la Semana Santa $^{10}$. Para ello hemos analizado las fuentes documentales que nos proporcionan el Archivo General del Arzobispado de Sevilla y los archivos de las distintas hermandades actuales de la ciudad hispalense. Los datos obtenidos los hemos dividido en varios apartados: las calidades y recibimientos de las mujeres, así como sus cuotas de entradas, sus actividades, estado civil y grupos sociales que formaron parte de las cofradías y el papel femenino dentro del gobierno de las mismas.

\section{CAlidAdes, RECIBIMIENTO Y CUOTAS DE ENTRADAS}

Ser recibida por una cofradía implicaba un procedimiento, proceso que comenzaba con la averiguación de la candidata, conocido como limpieza de sangre. En este informe de limpieza los mayordomos tenían la obligación de averiguar quién era porque si no es muger honrrada no sea recebida en esta sancta cofradia ${ }^{11}$. Ese procedimiento era exactamente el mismo que el de sus compañeros varones. Además de la limpieza, algunas cofradías establecían en sus reglas una serie de condiciones, prevaleciendo siempre la denegación de entrada a mujeres negras, mulatas, indias (para ellas estaban las cofradías étnicas), moriscas, judías o cristianas nuevas y a las descendientes de estos grupos. Ni siquiera aquellas que habían sido penitenciadas por el Santo Oficio o por algún otro tribunal.

En el caso de la Cofradía de la Vera Cruz el proceso era el siguiente: la pretendienta tenía que comunicar a algún cofrade su intención de formar parte de la Hermandad. Este, a su vez, se lo tenía que decir al mayordomo o escribano pero no en cabildo, teniendo este último la obligación de saber su vida y fama. Si la pretendienta tenía las calidades necesarias se debía saber en cabildo general y, con

8. Casquero Fernández 1997, p. 59

9. Pérez González 2012, p. 189.

10. Para otros estudios locales o castellanos podemos citar a Arias de Saavedra Alías, LópezGuadalupe Muñoz, 2017; López-Guadalupe Muñoz 1992, 1995 y 2016; López-Guadalupe Muñoz, Arias de Saavedra Alías, 2000; López-Guadalupe Muñoz, Castaño Jiménez, Díaz Sánchez, 2014; Río Barredo 2005; y Sánchez de Madariaga 1997, 1999, 2001 y 2014.

11. AHT, Carpeta 1, Libro de reglas, 1544, f. 14r. Capítulo XXVIII; AHQA, Legajo C, Libro de reglas de la Hermandad de la Quinta Angustia, 1541, f. 28r. Capítulo XXXI; Sánchez Herrero 2002, f. 17r. Capítulo XVII. 
la aprobación de todos, era admitida por cofrada. Si por el cabildo era acordado que no se le admitiera, el mayordomo le respondería lo mejor que pudiere no le dando a entender que no le quieren rescebir ${ }^{12}$.

Por su parte, la Cofradía de las Tres Caídas y Nuestra Señora del Arco ordenó en un cabildo celebrado el 25 de abril de 1632 que no fuera asentada ninguna hermana sin dar cuenta primero a uno de los alcaldes para que firmase la entrada, informándole a la susodicha si tenía alguno de los defectos que la regla disponía ${ }^{13}$. Documentamos dos casos en los que aparece el alcalde de esta Hermandad en 1631, Juan de Palacios, siendo testigo de la entrada de dos cofradas: María Sánchez, viuda en el Corral del Conde, y María de la Puerta, mujer de Gonzalo Ruiz, quien vivía en la Puerta de la Carne ${ }^{14}$.

Como calidades específicas tratamos a la Cofradía del Traspaso, la cual solicitaba que su cofrada no fuera revoltosa ni de vil trato ni bajo oficio ni de mala lengua ni negra ni mulata ni morisca ${ }^{15}$, ni india ${ }^{16}$. La de la Soledad establecía en sus Reglas que no debía ser reboltosa, ni escandalosa, ni de vil trato ni officio, ni de mala lengua ${ }^{17}$, ni mujer pública ${ }^{18}$, o la de Nuestra Señora de la Concepción, en Regina Angelorum, la cual solo admitían a personas de

honor y honrra y buena vida y fama y tales que se crea y entienda que con toda humildad y amor y buen zelo han de seruir a Dios (...) y mirar por el pro y utilidad y honrra della ${ }^{19}$.

Una vez aprobada la limpieza de sangre se procedía a su recibimiento, siempre como hermanas de luz (pues no podían hacer la disciplina), siendo posteriormente apuntadas en un libro de hermanas con su abecedario para que cada una fuera fácilmente hallada, con el día, mes y año y de dónde $\operatorname{eran}^{20}$ e incluso su estado y parentesco con un varón cofrade ${ }^{21}$. No conocemos con exactitud el proceso de recibimiento, sí tenemos constancia de que la cofrada, al igual que el cofrade, tenía que hacer un juramento, prometiendo guardar la Regla, ajustándose a las penas en

12. Sánchez Herrero 2002, f. 27v. Capítulo XXXI.

13. AHTCSI, 2. Secretaría, 2.1.1.1. Libro de registros de hermanos, Libro de entradas de hermanos, 1636, f. 161r. Cabildo de 25 de abril de 1632.

14. AHTCSI, 1. Gobierno, 1.1.2.1. Libro de Actas de Cabildos, Libro viejo de las hermanas y hermanos de esta cofradía, 1631, f. 60r.

15. Mira Caballos 2004, p. 61. Capítulo IX.

16. Calderón Berrocal 2002, f. 13v. Capítulo XIV; Herrera García 2002, f. 4v. Capítulo II.

17. Cañizares Japón 2014, p. 57. Capítulo IV; 2017, ff. 4r-4v. En término similares AHSL, Fondo Hermandad de la Concepción de Regina, 1. Libro de reglas, 1549, f. 15v. Capítulo XII.

18. Hermandad del Dulce Nombre 2009, f. 8r. "Sobre la forma de recebir hermanos".

19. AHSL, Fondo Hermandad de la Concepción de Regina, Libro de reglas, 1549, f. 15v. Capítulo XII.

20. Ibidem, f. 15r. Capítulo XI y f. 15r. Capítulo IX; AHEM, Libro de regla, 1595, f. 4v. Capítulo III.

21. AHSL, Fondo Hermandad de la Concepción de Regina, 1. Libro de reglas, 1549, f. 16r. Capítulo XII. 
caso de quebrantarla. Así era en la Cofradía de Nuestra Señora de la Esperanza y Sentencia de Cristo $^{22}$, haciendo además una protestación de $\mathrm{fe}^{23}$.

Toda mujer que quisiera entrar como hermana en cualquiera de las cofradías sevillanas tenía que pagar una cuota inicial (Tabla 1). Esta cuota era diferente para cada una de las corporaciones religiosas y estaba fijada en dinero o en cera. Respecto a la cuota en dinero, las mujeres tenían que pagar cuatro reales (Santo Sudario ${ }^{24}$ ) por quanto las reservamos de algunas penas y obligaciones que están puestas a los hermanos y cofrades (Esperanza y Sentencia ${ }^{25}$ ), cuatro reales más un maravedí por la misa del mes (Cinco Llagas y Nuestra Señora de las Angus$\operatorname{tias}^{26}$ ), cinco reales y medio (Expiración y Nuestra Señora del Patrocinio ${ }^{27}$ ), al menos ocho (Tres Caídas y Virgen del $\mathrm{Arco}^{28}$ ), ocho (Columnas y Azotes ${ }^{29}$ ), diez (Cofradía del Traspaso ${ }^{30}$ y Tres Caídas y Nuestra Señora del Arco, según regla de $1648^{31}$ ), doce (Nuestra Señora de Regla y Potencia de Cristo ${ }^{32}$ ), veintidós (Sole$\operatorname{dad}^{33}$ ), treinta reales, porque no tenían obligación de entierros y cabildos (Nuestra Señora de la Concepción ${ }^{34}$ ), un ducado $\left(\right.$ Expiración $\left.^{35}\right)$, dos (Dulce Nombre de María $^{36}$ ) y cuatro ducados (Buen Viaje ${ }^{37}$ ) más dos reales cada año por estar excusadas, cuyo excusado pagaban en mayo por la festividad de la Santa Cruz (Vera $\mathrm{Cruz}^{38}$ ).

Con respecto a la cuota en cera, únicamente documentamos un caso: una libra de cera en la Hermandad del Cristo del Amor ${ }^{39}$. También era posible pagar esta cuota con una combinación de ambas, tanto en dinero como en cera. Así por ejemplo se pagaba once reales y una candela de libra y media de cera (Dulce Nombre

22. AHEM, Libro de regla, 1595 , f. 17v. Capítulo XVII.

23. Ibidem, ff. 18r-18v. Capítulo XVIII.

24. García de la Concha Delgado 2002b, f. 148v. Capítulo III.

25. AHEM, Libro de regla, 1595, f. 3r. Capítulo I.

26. AHT, Carpeta 1, Libro de reglas, 1544, f. 6v. Capitulo XIII; AHQA, Legajo C, Libro de reglas de la Hermandad de la Quinta Angustia, 1541, ff. 15v-16r. Capítulo XVI.

27. AHCH, 1. Gobierno, 1.1.1.1. Libro de reglas, Caja 1, Libro 1, Libro de reglas, 1691, f. 33r. Capítulo XVII. Se trata de una copia notarial realizado en 1776 por Clemente Vicente Rodríguez, notario apostólico.

28. AHTCSI, 2. Secretaría, 2.1.1.1. Libro de registros de hermanos, Libro de entradas de hermanos, 1636, f. 161r. Cabildo de 25 de abril de 1632.

29. AGAS, Justicia, Hermandades, leg. 13025, exp. 7, f. 13r. Capítulo XIX.

30. Mira Caballos 2004, p. 61. Capítulo IX.

31. Jiménez Sampedro 2005, p. 879. Capítulo I.

32. AHP, Libro de reglas, 1601, f. 21r. Capítulo XXVII.

33. Cañizares Japón 2014, p. 57. Capítulo IV; 2017, f. 4r.

34. AHSL, Fondo Hermandad de la Concepción de Regina, 1. Libro de reglas, 1549, f. 16r y 12v. Capítulos XII y VI.

35. Herrera García 2002, f. 4v. Capítulo III.

36. Hermandad del Dulce Nombre 2009, f. 9v. "Sobre lo mismo y limosna de la entrada".

37. García de la Concha Delgado 2002c, f. 647r. Capítulo IV.

38. Sánchez Herrero 2002, ff. 16v-17r. Capítulo XVII.

39. AGAS, Justicia, Hermandades, leg. 09818, exp. 2, f. 5v. Capítulo XI. 
de Jesús ${ }^{40}$ ), dieciséis y una libra de cera (San Juan Evangelista ${ }^{41}$ ) y dos ducados y una candela de cera blanca de libra y media con el escudo de la Hermandad pintado, una jarra de Nuestra Señora de un cabo y por la otra parte un capelo de obispo que dio santa Verónica, en el caso de la Cofradía de la Coronación y Santa Verónica $^{42}$.

Todo esto estaba acompañado con medio real, a veces uno ${ }^{43}$, para el muñidor y el escribano que las asentaba en los libros. Por último, en ciertas ocasiones este pago inicial no fue especificado, como en la Cofradía de la Preciosa Sangre donde aparece en sus Reglas este término: lo que por nuestro cabildo fuere acordado ${ }^{44}$.

Un caso atípico fue el de la Hermandad del Santo Cristo del Silencio y Nuestra Señora de la Amargura, pues en ella no se pedía ninguna cuota de entrada, sino la averiguación de cada año con lo que buenamente pudieran ${ }^{45}$. De otras cofradías, al no haberse conservado sus reglas, desconocemos la cuota de entrada de las mujeres. A través de las cuentas de mayordomía sí constatamos que una hermana de la Cofradía de Nuestra Señora del Rosario y Oración en el Huerto pagó por su entrada cuatro reales en $1591^{46}$ y en 1608 una criada de Andrés Pinto pagó seis reales por su entrada ${ }^{47}$, por lo que desconocemos cuál era el pago exacto establecido.

La Cofradía de las Tres Caídas y Nuestra Señora del Arco ha tenido en pocos años dos Reglas: una en 1605, la fundacional, y otra en 1648. De la primera se han conservado muy pocos capítulos, pero no el que trataba sobre la entrada de las mujeres. Del segundo hay un capítulo que habla de las cuotas, pero no se mencionan a las mujeres, sino a hermanos de luz, ¿entrarían aquí las mujeres? Creemos que sí, pero con ciertas reservas. A través de los libros de hermanas hemos documentado las cuotas que pagaban algunas de las cofradas que entraron en 1631: Jerónima de San Miguel, hija de Cristóbal Francisco, y María de la Puerta, mujer de Gonzalo Ruiz, pagaron dos reales; cuatro pagaron María de la $\mathrm{O}$, mujer de Sebastián de Ojeda, doña Isabel de Molina e Isabel Jiménez, mujer de Andrés de Samaniego; y seis reales Isabel de la $\mathrm{Cruz}^{48}$.

Si la que entraba era mujer de cofrade la cuota era diferente. Por lo general pagaban la mitad de la cuota de las cofradas, además de su luminaria (Vera $\mathrm{Cruz}^{49}$ ), XIX.

40. AHQA, Legajo C, Libro de reglas de la Hermandad del Dulce Nombre, 1572, f. 13r. Capítulo

41. AHSP, 2. Hermandad de los Sagrados Clavos de Nuestro Redentor Jesucristo, Virgen María de los Remedios y San Juan Evangelista, Libro de reglas de 1595, s.f. Capítulo XV.

42. AGAS, Justicia, Hermandades, leg. 09796, exp. 9, ff. 8v-9r. Capítulo XIV.

43. AGAS, Justicia, Hermandades, leg. 09834, exp. 4.4., f. 36r. Capítulo VI; Granado Hermosín 2017, pp. 57-82.

44. Calderón Berrocal 2002, f. 13v. Capítulo XIV.

45. AHA, 1. Gobierno, 1.1. Reglas, proyectos de reglas y reglamentos, Libro de reglas, 1696, f. 9. Capítulo I.

46. AGAS, Justicia, Hermandades, leg. 09797, exp. 1, f. 364r.

47. AGAS, Justicia, Hermandades, leg. 09797, exp. 3, f. 13r. Cuenta de 1608.

48. AHTCSI, 1. Gobierno, 1.1.2.1. Libro de Actas de Cabildos, Libro viejo de las hermanas y hermanos de esta cofradía, 1631, ff. 60r-60v.

49. Sánchez Herrero 2002, ff. 16v-17r. Capítulo XVII. 
una candela de media libra de cera (Dulce Nombre de Jesús ${ }^{50}$ ), o su luminaria y tres maravedís por misas (Cinco Llagas y Nuestra Señora de las Angustias ${ }^{51}$ ), una vela de libra y media y un real al escribano y otro al muñidor y no se le pueda llevar pena por las faltas que hiciere por ser como son mujeres (Traspaso ${ }^{52}$ ) o dos ducados (Buen Viaje ${ }^{53}$ ). Este pago era siempre que el hermano siguiera vivo, porque si este moría su mujer heredaba la candela mientras que no se casara de nuevo, pagando su luminaria y tres maravedís por misas. Si la mujer, madre o hija de un cofrade de la Hermandad de las Tres Caídas y Madre de Dios del Arco quería entrar tenía que pagar dos reales ${ }^{54}$.

Otra distinción que encontramos en la documentación es la de hermanas de gracias, es decir, aquellas mujeres que querían entrar a formar parte de la cofradía para solamente ganar las gracias y perdones que esta tuviera. Así ocurrió en la Hermandad del Dulce Nombre de Jesús, siendo asentadas en el libro de cofrades de gracia y no daban nada de entrada, saluo si él de su voluntad por su devoción quisiere dar alguna limosna ${ }^{55}$.

Tabla 1. Cuotas de entradas de las mujeres (ss. XVI-XVII).

\begin{tabular}{|l|c|c|}
\hline \multicolumn{1}{|c|}{ COFRADÍA } & COFRADA & MUJER DE COFRADE \\
\hline Amor & 1 libra de cera & - \\
\hline Buen Viaje & 4 ducados & 2 ducados \\
\hline Cinco Llagas & 4 reales & La mitad \\
\hline Columnas y Azotes & 8 reales & - \\
\hline Coronación y Santa Verónica & $\begin{array}{c}\text { 2 ducados y } 1 \text { candela de } \\
\text { libra y media }\end{array}$ & - \\
\hline Dulce Nombre de Jesús & $\begin{array}{c}11 \text { reales y } 1 \text { candela de } \\
\text { libra y media }\end{array}$ & candela de media libra \\
\hline Dulce Nombre de María & 2 ducados & - \\
\hline Esperanza y Sentencia & 4 reales & - \\
\hline Expiración & 1 ducado & - \\
\hline $\begin{array}{l}\text { Expiración y Nuestra Señora del } \\
\text { Patrocinio }\end{array}$ & 5 reales y medio & - \\
\hline
\end{tabular}

50. AHQA, Legajo C, Libro de reglas de la Hermandad del Dulce Nombre, 1572, f. 11v. Capítulo VIII.

51. AHT, Carpeta 1, Libro de reglas, 1544, f. 6v. Capítulo XIII; AHQA, Legajo C, Libro de reglas de la Hermandad de la Quinta Angustia, 1541, ff. 15v-16r. Capítulo XVI.

52. Mira Caballos 2004, p. 62. Capítulo IX.

53. García de la Concha Delgado 2002c, f. 647r. Capítulo IV.

54. AHTCSI, 2. Secretaría, 2.1.1.1. Libro de registros de hermanos, Libro de entradas de hermanos, 1636, f. 161r. Cabildo de 25 de abril de 1632.

55. AHQA, Legajo C, Libro de reglas de la Hermandad del Dulce Nombre, 1572, f. 14r. Capítulo $\mathrm{X}$. 


\begin{tabular}{|l|c|c|}
\hline \multicolumn{1}{|c|}{ COFRADÍA } & COFRADA & MUJER DE COFRADE \\
\hline Nuestra Señora de la Concepción & 30 reales & - \\
\hline Nuestra Señora de las Angustias & 4 reales & La mitad \\
\hline $\begin{array}{l}\text { Nuestra Señora de Regla y Poten- } \\
\text { cia de Cristo }\end{array}$ & 12 reales & - \\
\hline San Juan Evangelista & 16 reales y 1 libra de cera & - \\
\hline Santo Sudario & 4 reales & - \\
\hline Nuestra Señora de la Soledad & 22 reales & - \\
\hline Traspaso & 10 reales & vela de libra y media \\
\hline $\begin{array}{l}\text { Tres Caídas y Nuestra Señora del } \\
\text { Arco (1605) }\end{array}$ & 8 reales al menos & - \\
\hline $\begin{array}{l}\text { Tres Caídas y Nuestra Señora del } \\
\text { Arco (1648) }\end{array}$ & 10 reales & La mitad \\
\hline Vera Cruz & 4 ducados & - \\
\hline
\end{tabular}

Además de esta cuota de entrada, las mujeres tenían que pagar cada año su averiguación, que podía ser treinta y seis maravedís (Preciosa Sangre ${ }^{56}$ ), lo que cada una pudiera siempre que fuera más de un real (Santo Sudario $\left.{ }^{57}\right)$, un real $(\mathrm{Co}-$ lumnas y Azotes ${ }^{58}$ ) por estar excusadas el día de Santa María de Agosto (Cinco Llagas y Nuestra Señora de las Angustias ${ }^{59}$ ), un real por la luminaria en la fiesta de San Juan Evangelista por el mes de mayo (San Juan Evangelista ${ }^{60}$ ), dos (Expiración y Nuestra Señora del Patrocinio ${ }^{61}$ y Dulce Nombre de María ${ }^{62}$ ), tres reales (Jesús Nazareno ${ }^{63}$ y Expiración ${ }^{64}$ ) o nada durante la vida de su marido, hermano de la hermandad. Pero si este moría antes que ella, la cofrada era obligada a pagar luminaria y demás cosas como a las demás hermanas que entraron de por $s i^{65}$, las cuales sí pagaban un real de luminaria en la fiesta de la Circuncisión de Cristo, más los quartos de los meses y medio real de los Todos Sanctos (Dulce Nombre de Jesús ${ }^{66}$ ). Fueron dos reales los que dio Isabel Ramírez, hermana de la Cofradía

56. Calderón Berrocal 2002, f. 14r. Capítulo XVI.

57. García de la Concha Delgado 2002b, f. 151r. Capítulo VIII.

58. AGAS, Justicia, Hermandades, leg. 13025, exp. 7, f. 13r. Capítulo XIX.

59. AHT, Carpeta 1, Libro de reglas, 1544, f. 6v. Capítulo XIII; y AHQA, Legajo C, Libro de reglas de la Hermandad de la Quinta Angustia, 1541, ff. 15v-16r. Capítulo XVI.

60. AHSP, 2. Hermandad de los Sagrados Clavos de Nuestro Redentor Jesucristo, Virgen María de los Remedios y San Juan Evangelista, Libro de reglas de 1595, s.f. Capítulo XVI.

61. AHCH, 1. Gobierno, 1.1.1.1. Libro de reglas, Caja 1, Libro 1. Libro de reglas, 1691, f. 33v. Capítulo XVII. Se trata de una copia notarial realizado en 1776 por Clemente Vicente Rodríguez, notario apostólico.

62. Hermandad del Dulce Nombre 2009, f. 10r. "Sobre las averigvaciones".

63. AAJNS, Libro de reglas, 1578, f. 46v. Capítulo XXXIII; AGAS, Justicia, Hermandades, leg. 13025, exp. 6, f. 29v. Capítulo XXXIII.

64. Herrera García 2002, f. 17r. Capítulo XXXIV.

65. AHQA, Legajo C, Libro de reglas de la Hermandad del Dulce Nombre, 1572, f. 12r. Capítulo VIII.

66. Ibidem, f. 13r. Capítulo XIX. 
de las Tres Necesidades, para su averiguación en $1686^{67}$, veinte reales Elvira de Santana ${ }^{68}$ o seis doña Isabel Sánchez y doña Sebastiana de Tamara para la misma Hermandad $^{69}$. Como no ha llegado a nuestra actualidad el Libro de Reglas de esta Cofradía desconocemos cuál era el pago exacto de las averiguaciones, aunque creemos que muy probablemente pudiera ser seis reales.

También era posible entrar como hermana mediante la herencia. A la muerte del marido la mujer podía heredar su candela hasta que esta volviera a casarse, pues de hacerlo la perdería ${ }^{70}$. En este caso, la viuda pagaba únicamente la candela, pidiendo su admisión el mismo año del fallecimiento del marido (Coronación y Santa Verónica ${ }^{71}$ ) o a los tres meses del fallecimiento (Nuestra Señora de la Concepción ${ }^{72}$ ), dando de limosna una libra y media de cera y un real para los presos pobres de la cárcel (Jesús Nazareno ${ }^{73}$ ), dos reales (Nuestra Señora de Regla y Potencia de Cristo $^{74}$ y Columnas y Azotes ${ }^{75}$ ). Quizás, como ya fue destacado por Muñoz Fernández, esta mujer tuviera la condición como mera usufructuaria, hasta que los hijos llegaran a la mayoría de edad ${ }^{76}$.

También estaba la posibilidad de que heredase la candela la hija mayor, aunque se prefería siempre al varón que a la mujer ${ }^{77}$. Así, por poner algunos ejemplos, documentamos en la Cofradía de la Vera Cruz a Juana Margarita, quien heredó en 1621 la vela de su padre, Francisco García, confitero $^{78}$, o doña Leonor de Rivera Molledo, hija de Andrés de Molledo ${ }^{79}$. Aunque se podía heredar la vela del hombre no se podía hacer lo mismo cuando era la cofrada la que moría (Nuestra Señora de la Concepción ${ }^{80}$ ).

Otro caso parecido, aunque no ya de herencia, era lo que ocurría en la Cofradía de Nuestra Señora de la O y Santa Brígida, donde si era la mujer del cofrade la que moría y este se casaba de nuevo, la segunda mujer era considerada como cofrada y recibía todos los privilegios, así como también gozaba de estos las hijas del cofrade mientras viviera en casa del padre ${ }^{81}$.

67. AHCRR, 1. Gobierno, 1.3.1. Libro de actas 1610-1682, Caja 3, f. 116r. Cuenta de 1686-1687.

68. Ibidem, f. 168r. Cuenta de 1653.

69. Ibid., f. 226v. Cuenta de 1682 .

70. Mira Caballos 2004, p. 73. Capítulo XXVIII; AGAS, Justicia, Hermandades, leg. 09885, exp. 1, f. 78r. Capítulo XI; Sánchez Herrero 2002, ff. 16v-17r. Capítulo XVII.

71. AGAS, Justicia, Hermandades, leg. 09796, exp. 9, f. 8r. Capítulo XII.

72. AHSL, Fondo Hermandad de la Concepción de Regina, Libro de reglas, 1549, f. 16v. Capítulo XIII.

73. AAJNS, Libro de reglas, 1578, f. 26v. Capítulo XIX; AGAS, Justicia, Hermandades, leg. 13025, exp. 6, f. 16r. Capítulo XIX.

74. AHP, Libro de reglas, 1601, f. 20v. Capítulo XXVII.

75. AGAS, Justicia, Hermandades, leg. 13025, exp. 7, f. 13r. Capítulo XIX.

76. Muñoz Fernández 1991, p. 99.

77. AHSL, Fondo Hermandad de la Concepción de Regina, Libro de reglas, 1549, f. 16v. Capítulo XIII.

78. AHVC, Libro 10, Libro de hermanos, 1598-1626, f. 99v.

79. Ibidem, f. $103 \mathrm{r}$.

80. Ibid., f. 17r. Capítulo XIII.

81. AHO, I. Reglas y constituciones, Libro de reglas, 1566, f. 21r. Capítulo XLV y Capítulo XLVI. 


\section{LAS COFRADAS: SU ANÁLISIS SOCIO-ECONÓMICO}

La mujer no dispuso de posibilidad para formar asociaciones propias, aunque tampoco se prohibió su pertenencia a las masculinas, gozando de los mismos o similares derechos que los hombres en las cofradías, aunque esta participación lo fue en función de ser esposa, viuda o hija de cofrade ${ }^{82}$. La intervención directa de las mujeres en las cofradías fue de dos tipos ${ }^{83}$ : la de aquellas que entraron por voluntad propia y la de aquellas que accedieron a través de su matrimonio con un cofrade, distinguiéndose entre las mujeres de cofrades y las viudas de estos.

Desgraciadamente no son muchos los libros de asientos de hermanas cofradas que han llegado hasta nosotros a día de hoy y los pocos ejemplos con los que contamos, cuatro libros en total de tres cofradías, tampoco arrojan mucha información con respecto al grupo de mujeres que formaban las hermandades, apareciendo en numerosas ocasiones únicamente el nombre y apellido, en algunos casos incluso su vinculación familiar con un varón. A estos cuatro libros les sumamos otros tres que se conservan en el archivo de la Hermandad de Nuestra Señora de la Soledad. Estos no los hemos podido estudiar por dos razones: la primera porque ha sido imposible su consulta y la segunda porque el investigador de esta corporación, Cañizares Japón, no hace ni una sola mención a este colectivo en su estudio ${ }^{84}$.

En este apartado tenemos que aclarar que no hemos estudiado todas las hermanas que formaron parte de las cofradías, sino solo aquellas que en los libros de hermanas nos da información complementaria al nombre y apellido. Tampoco nos interesa para este estudio el número total de cofradas, además no sería posible por la falta de libros. Por ejemplo, y por poner un caso del que disponemos más documentación, el número de entrada de mujeres en la Cofradía de Jesucristo de las Tres Caídas y Nuestra Señora del Arco era, en todo el siglo XVII, de 240 entradas documentadas (Gráfico 1).

Siguiendo a Muñoz Fernández, en las cofradías la familia natural se proyectaba hacia la suprafamilia espiritual y a los vínculos de parentesco real se superponían los espirituales: el propio marido y los otros cofrades, también esposos, padres o hermanos reales o espirituales de las cofradas legitiman con su militancia la presencia femenina $^{85}$. Al entrar en las cofradías y hermandades, la mujer, al menos la que entró por voluntad propia, escapaba del control de los vínculos de la familia natural, recayendo en ella únicamente los mecanismos reguladores de la familia espiritual, los miembros varones de las corporaciones.

82. Casquero Fernández 1997, p. 59.

83. Arboleda Goldaracena, Pérez González 2016, p. 116.

84. Cañizares Japón 2007.

85. Muñoz Fernández 1991, p. 112. 


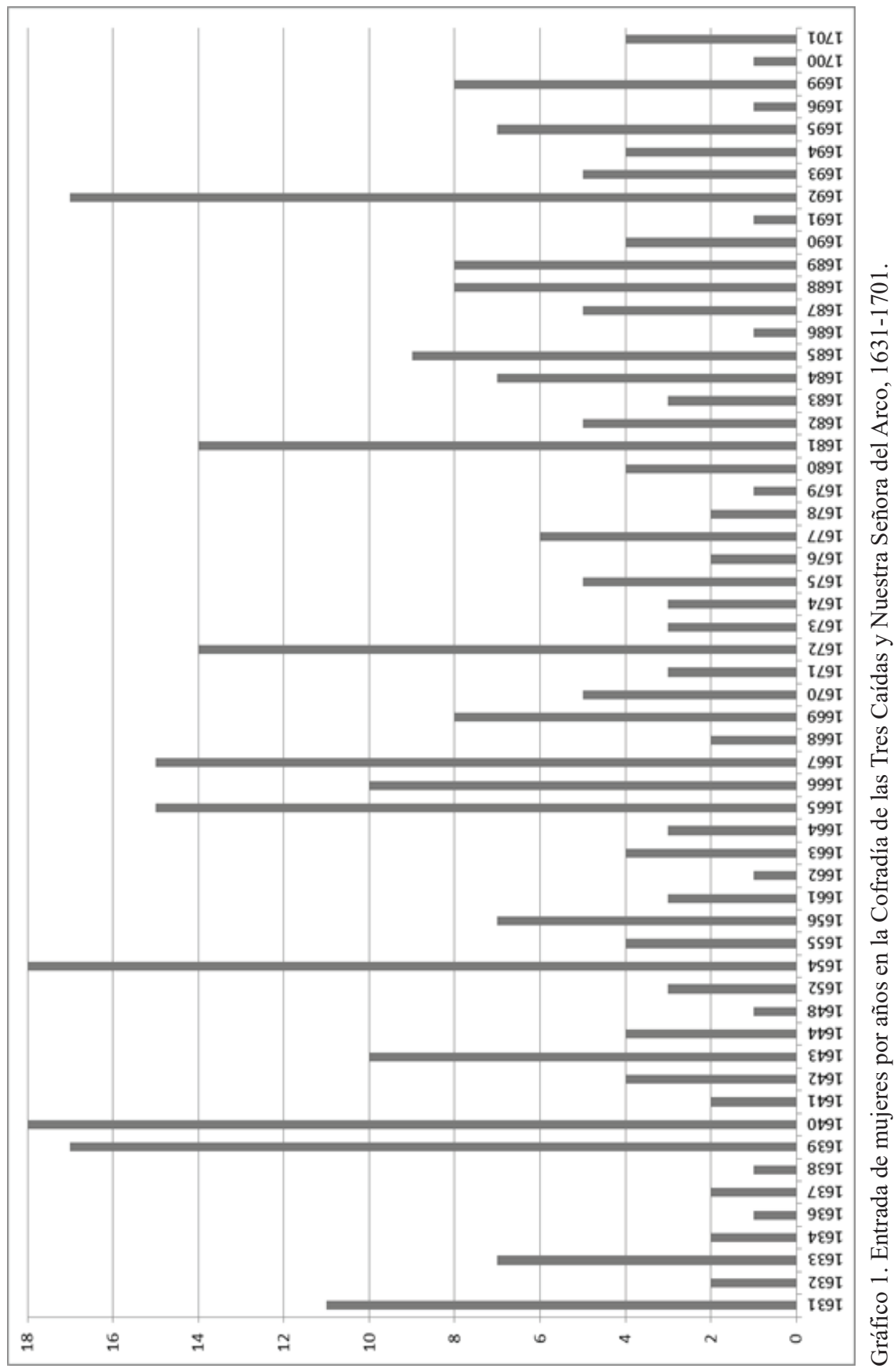


3.1. Grupos de parentescos: las relaciones entre hombres y mujeres

Comenzando por el estudio del parentesco es muy interesante el trabajo que hizo Muñoz Fernández de esta cuestión mediante dos ejemplos de cofradías madrileñas ${ }^{86}$. Hemos estudiado un total de 646 hermanas. Centrándonos en sus parentescos con algún varón (Tabla 2) encontramos como hermana de un caso que representa el 0,2\%, como hija de 62 casos que equivale al 9,6\% del total, madre de uno (0,2\%), mujer de 297 casos documentados (46\%), nieta de dos (0,3\%), relacionada con o familiar de, pues no se especifica exactamente su parentesco, uno $(0,2 \%)$, sobrina de tres $(0,5 \%)$, suegra de un único caso $(0,2 \%)$ y viuda de 33 $(5,1 \%)$.

Tabla 2. Porcentajes de parentesco entre la cofrada y el hermano.

\begin{tabular}{|l|c|c|}
\hline \multicolumn{1}{|c|}{ PARENTESCO } & CASOS & PORCENTAJE \\
\hline hermana de & 1 & $0,2 \%$ \\
\hline hija de & 62 & $9,6 \%$ \\
\hline madre de & 1 & $0,2 \%$ \\
\hline mujer de & 297 & $46 \%$ \\
\hline nieta de & 2 & $0,3 \%$ \\
\hline relacionada con & 1 & $0,2 \%$ \\
\hline sobrina de & 3 & $0,5 \%$ \\
\hline suegra de & 1 & $0,2 \%$ \\
\hline viuda de & 33 & $5,1 \%$ \\
\hline sin definir & 245 & $37,9 \%$ \\
\hline DOCUMENTADAS & 646 & $100 \%$ \\
\hline
\end{tabular}

No es ninguna novedad que la forma más común, al menos a través de la documentación estudiada, fuera que las mujeres entraran en las cofradías por medio de sus maridos, ya hermanos de las mismas, o entrando el mismo día el matrimonio conjuntamente. Así, por ejemplo, documentamos algunos casos como el de doña Francisca Vela, mujer del mercader Gaspar de Salcedo, quien entró en la Hermandad del Traspaso en 1550 o el de doña Jerónima de Mena, mujer de Diego de la Fuente, también mercader, quien entró el 25 de febrero de ese mismo año ${ }^{87}$, por poner algunos de los 297 documentados.

Aunque no era la única forma de acceso, pues también había otras relacionadas con el varón. En orden decreciente de casos encontramos la de la madre del co-

86. Muñoz Fernández 1990, pp. 369-391.

87. AHGP, Libro 41, Libro de asiento de hermanos, 1551-1654, s.f. 
frade, mencionando a Catalina Antonia Zapata ${ }^{88}$, madre de Juan Antonio y vecina de la collación de San Roque, quien se asentó en 1681 en la Cofradía de las Tres Caídas y Nuestra Señora del Arco. Relacionado con ello, documentamos a la suegra del hermano. El proceso de Catalina Sánchez es, por lo menos, curioso y digno de anotar. Esta señora era suegra de Juan Ruiz y madre de María de los Santos. Su hija aparece documentada por primera vez el 25 de marzo de $1633^{89}$, fecha en la que se trasladó al nuevo libro (que es el que se ha conservado), como mujer del dicho Juan Ruiz en la Hermandad de las Tres Caídas y Nuestra Señora del Arco. Ese mismo día también se documenta el traslado de su madre, la mencionada Catalina Sánchez, pero no aparece como madre de María, sino como suegra de Juan, lo que nos hace pensar en una cierta preeminencia del varón frente a la mujer a la hora del acceso ${ }^{90}$.

Ampliando los lazos familiares están las hijas de cofrades. Por poner un ejemplo documentamos el 17 de marzo de 1550 a doña María de Contreras, hija de Juan Francisco de Contreras, quien entró en la Cofradía del Traspaso. La cuestión es si esta señora, al igual que otras, entró en vida del padre o, por el contrario, heredó la candela una vez fallecido este, pues la documentación guarda silencio con este tema. Por último tenemos a las hermanas carnales de los cofrades (doña Isabel Ramírez, hermana de Andrés Núñez, entró en 1697 en la Hermandad de Nuestra Señora de la O y Santa Brígida ${ }^{91}$ ), a las nietas (en 1699 entraron en la misma Cofradía doña Leonor María, nieta de Luis Figuera, y doña Josefa Plácida, nieta de Manuel de Soto ${ }^{92}$ ) y a las sobrinas (para la misma, por ejemplo, en 1693 doña Sebastiana María, sobrina de Pedro de Castro $^{93}$ ).

Por último, documentamos un grueso grupo de viudas, estudiadas por Pérez González $^{94}$. Estas, sin duda alguna, entraron heredando la candela de sus maridos fallecidos. Por poner únicamente un ejemplo de cada cofradía de las que tenemos registros de hermanas, Juana Díaz ${ }^{95}$, viuda de Agustín Díaz, entró en 1553 en la Cofradía del Traspaso; María Díaz ${ }^{96}$, viuda de Sancho Martín, se asentó en la Hermandad de la Oración en el Huerto y Nuestra Señora del Rosario el 26 de octubre de 1586; Ana Díaz ${ }^{97}$, viuda de Francisco de Castro, entró el 5 de abril de 1640 en la Cofradía de las Tres Caídas y Nuestra Señora del Arco; y doña Jerónima de San José $^{98}$, viuda de Antonio de los Santos, quien entró en 1684 en la Hermandad de Nuestra Señora de la O y Santa Brígida.

88. AHTCSI, 2. Secretaría, 2.1.1.1. Libro de registros de hermanos, Libro de entradas de hermanos, 1636, f. 192v.

89. AHTCSI, 1. Gobierno, 1.1.2.1. Libro de Actas de Cabildos, Libro viejo de las hermanas y hermanos de esta cofradía, 1631, f. 62 r.

90. Ibidem.

91. AHO, III. Registro de cofrades y cofradas, Asiento de hermanos, 1675-1718, f. 41r.

92. Ibid., ff. $44 \mathrm{r}$ y $44 \mathrm{v}$.

93. Ibid., f. 30r.

94. Pérez González 2010, pp. 31-54.

95. AHGP, Libro 41, Libro de asiento de hermanos, 1551-1654, s.f.

96. AGAS, Justicia, Hermandades, leg. 09797, exp. 1, s.f.

97. AHTCSI, 1. Gobierno, 1.1.2.1. Libro de Actas de Cabildos, Libro viejo de las hermanas y hermanos de esta cofradía, 1631, f. 38v.

98. AHO, III. Registro de cofrades y cofradas, Asiento de hermanos, 1675-1718, f. 8r. 
También estaba la posibilidad, aunque menos común, de que fuera el varón el que entrara en la cofradía por parte de su madre cofrada, sin conocer si se produjo estas entradas por herencia o en vida de ella. Documentamos a Vicente García, hijo de Marina García, quien vivía en casa de Francisco de Vargas, el cual entró en la Cofradía del Sagrado Lavatorio y Nuestra Señora del Pópulo el 9 de marzo de 1614 ${ }^{99}$; a Diego de Salazar, hijo de doña Ana de Salazar, quien entró en la misma Hermandad el 12 de abril de 1615 ${ }^{100}$; Francisco de Abero, hijo de doña Clara de Medina, cofrade desde el 24 de marzo de 1619 de la Cofradía del Traspaso ${ }^{101}$; los hermanos Francisco Luis de Campos y Juan Antonio de Campos, hijos de doña Isabel de Velasco, quienes entraron en la Cofradía de Montserrat el 4 de marzo de 1629102; Alonso Román, hijo de Inés López, el 5 de abril de 1639 en la Hermandad del Traspaso ${ }^{103}$ y Gaspar Jiménez Coronado, hijo de doña Luisa de Abrego, quien entró en la Cofradía de Montserrat el 27 de marzo de $1640^{104}$.

\subsection{Estado civil, religiosas, extranjeras y nobleza}

\subsubsection{Doncellas ${ }^{105}$}

Las doncellas, estudiadas por Sánchez Herrero ${ }^{106}$, fueron un grupo social importante pues serían ellas, en muchos casos, las que primeramente se podían beneficiar de las dotes a doncellas, tarea benéfico-asistencial que practicaban muchas hermandades durante este periodo y posteriormente. La doncella era la adolescente que se preparaba para el destino que le eligieran sus padres ${ }^{107}$. El modelo de doncella que predicaban los moralistas incluía la obediencia, la humildad, la modestia, la discreción y la vergüenza, entre otras cualidades. Diez son los casos que hemos podido documentar, que son las siguientes:

Tabla 3. Doncellas pertenecientes a cofradías.

\begin{tabular}{|l|c|c|}
\hline \multicolumn{1}{|c|}{ NOMBRE } & ENTRADA & COFRADÍA \\
\hline Beatriz Herrero $^{1}$ & 1553 & Traspaso \\
\hline Jerónima de Meneses $^{2}$ & 1553 & Traspaso \\
\hline
\end{tabular}

99. APSNB, Fondo parroquia de Santa María la Blanca, Libro de recepción de hermanos de la Cofradía de Nuestra Señora del Pópulo y Sagrado Lavatorio, 1610, f. 60r.

100. Ibidem, f. 65r.

101. AHGP, Libro 42, Libro de asiento de hermanos, 1618-1715, f. 63v.

102. AHM, 3. Secretaría, 3.3. Registro de hermanos, Libro registro de hermanos, 1606-1698, f. $103 \mathrm{r}$.

103. AHGP, Libro 42, Libro de asiento de hermanos, 1618-1715, f. 153v.

104. AHM, 3. Secretaría, 3.3. Registro de hermanos, Libro registro de hermanos, 1606-1698, f. $144 \mathrm{v}$.

105. Podemos consultar a García Herrero 2018.

106. Sánchez Herrero 1995, pp. 69-125; 1997, pp. 163-192.

107. Vigil 1986, p. 18. 


\begin{tabular}{|l|c|c|}
\hline \multicolumn{1}{|c|}{ NOMBRE } & ENTRADA & COFRADÍA \\
\hline Isabel Bautista $^{3}$ & 8 de marzo de 1592 & Traspaso \\
\hline Mariana de los Reyes $^{4}$ & 1620 & Traspaso \\
\hline doña Catalina Sarmiento $^{5}$ & 1620 & Traspaso \\
\hline Jerónima de Soto Morena $^{6}$ & 12 de abril de 1620 & Traspaso \\
\hline María de la Asunción $^{7}$ & 1621 & Traspaso \\
\hline doña Juana de Lizama $^{8}$ & 1622 & Traspaso \\
\hline Jerónima Guillén $^{9}$ & 1629 & Traspaso \\
\hline Leonor de Salazar $^{10}$ & 23 de abril de 1656 & $\begin{array}{c}\text { Tres Caídas y Nuestra Señora del } \\
\text { Arco }\end{array}$ \\
\hline
\end{tabular}

1. AHGP, Libro 4, Libro de asiento de hermanos, 1551-1654, s.f.

2. Ibidem

3. Ibid., f. 22 r.

4. Ibid., f. 93v.

5. Ibid., f. $94 \mathrm{r}$.

6. Ibid., f. 94r.

7. Ibid., f. $95 \mathrm{r}$.

8. Ibid., f. 98r. Era sobrina de Pedro López de Lizama.

9. AHGP, Libro 41, Libro de asiento de hermanos, 1551-1654, f. 100r.

10. AHTCSI, 2. Secretaría, 2.1.1.2. Libro de registro de hermanas, Libro de entradas de hermanas, $1663-1710$, f. 5 v.

\subsubsection{Viudas}

Hoy día no podemos negar que la ideología imperante de la época era la de que la mujer no podía ser dueña por completo de su destino, no estando capacitada, según tratados de la época ${ }^{108}$, para regirse por sí sola ${ }^{109}$. El marido actuaba in loco parentis, es decir, se convertía en tutor de su esposa, gestionando sus bienes, sus rentas, etc. Únicamente escapaban a esta autoridad las solteras mayores de edad (25 años), las monjas y las viudas. Bajo la denominación de viudas se insertaban no solo a las propiamente dichas, sino a las separadas por sentencia eclesiástica, a las solteras con casa propia, a las casadas que tenían a sus maridos en paradero desconocido, etc. ${ }^{110}$. Entre los grupos medios urbanos se dio un tipo de mujer que, muerto el marido, se hizo cargo de la dirección de sus negocios y de la jefatura de la familia ${ }^{111}$. Aunque ya hemos hablado de las viudas de, estas que traemos aquí, en cambio, entraron sin parentesco con un hombre, lo que sugiere que accedieron a las cofradías por ellas mismas por devoción a cierta imagen. Hemos documentado un total de 43 desde 1551 hasta 1697 (34 en la Cofradía del Traspaso, ocho en la de las Tres Caídas y Nuestra Señora del Arco y una en la de Expiración y Nuestra Señora del Patrocinio).

108. Soria Mesa 2003, p. 462.

109. Un ejemplo del papel de la mujer en el matrimonio podemos verlo en León 2005.

110. Domínguez Ortiz 1986, p. 147.

111. Vigil 1986, p. 200. 


\subsubsection{Mujeres religiosas}

Las mujeres castellanas disponían de numerosas opciones a la hora de expresar su devoción ${ }^{112}$ pero será el nivel económico de las mismas lo que determinó la elección de una expresión u otra. La profesora Pérez González, estudiando la mujer en Sevilla a finales de la Edad Media, exponía que la existencia de mujeres que de forma espontánea se retiran a un lugar apartado o se recogen con el fin de vivir una vida religiosa es un fenómeno frecuente y bastante extendido ${ }^{113}$, pudiendo adoptar distintas formas externas de manifestación. Para nuestras cofradías hemos podido documentar dos de estas manifestaciones: las beatas y las monjas ${ }^{114}$.

\subsubsection{Beatas $^{115}$}

Las beatas eran

mujeres que, sin abandonar el contacto con el mundo, se dedicaron a hacer una vida de perfección religiosa distribuidas por todo el tejido urbano, en el interior de sus propias casas, sin necesidad de vincularse con ninguna institución. Valoran especialmente la participación en la vida activa, el mantenimiento del contacto con el mundo y constituyen una plasmación de los ideales mendicantes ${ }^{116}$.

Para el caso de la ciudad de Sevilla, Avellá Cháfer, citando a Melquiades Andrés y su obra, La teología española en el siglo XVI publicado en 1977, habló del masivo fenómeno de las beatas ${ }^{117}$ entre 1530 y 1570, sobre todo en Extremadura, Jaén y Sevilla, para el que daba dos explicaciones para ello: 1) una preocupación por parte de las mujeres por la perfección cristiana, y 2) un despoblamiento de los hombres en España por la conquista y colonización de América.

Podríamos decir que el florecimiento de las beatas en la ciudad de Sevilla se produjo ya en el siglo $\mathrm{XV}^{118}$, siendo más numerosas a partir del segundo cuarto del XVI, fecha en la que las documentamos en nuestras hermandades y cofradías, seis que fueron hermanas de la Cofradía de Nuestra Señora del Traspaso, mientras que una era de la Hermandad de Nuestra Señora del Rosario y Oración en el Huerto, documentadas desde 1553 hasta 1610 (Tabla 4). Con respecto a esta última, Isabel de León, beata del Carmen, se documenta en 1591 dando una limosna de 44 reales de vellón para cera a la dicha Cofradía, desconociéndose su fecha de entrada al no conservarse los libros de hermanos ${ }^{119}$.

112. Poska, Lehfeldt 2002, p. 37.

113. Pérez González 2005, p. 91.

114. Véase Miura Andrades 1998.

115. Sobre estudios de las beatas en España, véase Avellá Cháfer 1982; Miura Andrades 1989; Muñoz Fernández 1994; Pons Fuster 1991.

116. Pérez González 2005, p. 133; Miura Andrades 1991, p. 141.

117. Avellá Cháfer 1982, p. 102.

118. Pérez González 2005, p. 135.

119. AGAS, Justicia, Hermandades, leg. 09797, exp. 1, f. 16v. 
Tabla 4. Beatas pertenecientes a cofradías.

\begin{tabular}{|l|c|c|}
\hline \multicolumn{1}{|c|}{ NOMBRE } & ENTRADA & COFRADÍA \\
\hline Catalina de San Francisco $^{1}$ & 1553 & Traspaso \\
\hline Ana de San Jerónimo $^{2}$ & 25 de abril de 1590 & Traspaso \\
\hline Isabel de León $^{3}$ & documentada en 1591 & $\begin{array}{c}\text { Oración y Nuestra Señora del } \\
\text { Rosario }\end{array}$ \\
\hline Juana Bautista $^{4}$ & 15 de marzo de 1603 & Traspaso \\
\hline Leonor de Tapia $^{5}$ & 8 de abril de 1607 & Traspaso \\
\hline María de Jesús $^{6}$ & 28 de marzo de 1610 & Traspaso \\
\hline${\text { (desconocida })^{7}}^{7}$ & 1614 & $\begin{array}{c}\text { Oración y Nuestra Señora del } \\
\text { Rosario }\end{array}$ \\
\hline
\end{tabular}

1. AHGP, Libro 41, Libro de asiento de hermanos, 1551-1654, s.f.

2. Ibidem, f. 20v.

3. AGAS, Justicia, Hermandades, leg. 09797, exp. 1, f. 16v.

4. AHGP, Libro 41, Libro de asiento de hermanos, 1551-1654, f. 38v.

5. Ibidem, f. 55 r.

6. Ibid., f. 61r.

7. AGAS, Justicia, Hermandades, leg. 09797, exp. 3, f. 78r. Cuentas de 1614. Desconocemos el nombre de la beata al no conservarse los libros de asiento de hermanas.

A través de nuestro estudio sobre la religiosidad laica en la villa de Alcalá de Guadaíra (Sevilla) durante el siglo XVII ${ }^{120}$ documentamos a Ana de San Jerónimo, beata franciscana, quien fue santera o ermitaña en la ermita de Santa Catalina de Siena, collación de San Miguel, de la dicha villa desde 1604 a $1605^{121}$. ¿Se trataría de la misma beata hermana de la Cofradía del Traspaso? Pudiera ser que sí, pues la santera de Alcalá tenía, en 1605, 56 años y llevaba una vida ejemplar, tanto en lo personal como en lo espiritual, pues el prior y canónigo de la Catedral de Sevilla, el doctor Juan García Bahamonde, aprobó en un documento la confianza, buen proceder e vida de la madre Ana de San Gerónimo ${ }^{122}$. En dicho documento, fechado en 1605, se le aprobó una prórroga para seguir habitando en la ermita de Santa Catalina de Siena, atendiendo a que en la dicha hermita ha hecho muchos reparos y ha cumplido con su obligación virtuosa y ejemplarmente y en ello será Dios Nuestro Señor seruido y sus santos. También avala la hipótesis de que sean la misma persona el hábito. Ana de San Jerónimo se unió a la orden franciscana y la Hermandad del Traspaso en 1590 se encontraba en el Convento del Valle, extramuros de la ciudad y perteneciente a la collación de San Román, cuya orden era también la franciscana.

120. Granado Hermosín 2016. Esto fue un capítulo de Granado Hermosín 2014.

121. Granado Hermosín 2016, p. 213. El documento original se encuentra en AGAS, Gobierno, Priorato de ermitas, leg. 05301, s.f.

122. Ibidem. 


\subsubsection{Monjas}

La historia de los monasterios y conventos femeninos sevillanos es ya bastante conocida a partir de los estudios que desde el siglo XVI hasta nuestros días han realizado numerosos investigadores, tanto desde el punto de vista histórico como del artístico ${ }^{123}$. No pretendemos en este apartado hacer una historia de los conventos de religiosas de Sevilla, tampoco es nuestro estudio. Simplemente tratamos aquellas monjas que formaron parte de las cofradías penitenciales sevillanas.

Las monjas eran aquellas mujeres que habían profesado en una orden religiosa determinada para dedicar toda su vida a Cristo, a la vida contemplativa y al perfeccionamiento espiritual ${ }^{124}$. En todos los casos documentados desconocemos sus nombres, pues entraron como colectivo y no individualmente. Cronológicamente documentamos en 1591 la entrada de las monjas del convento de Santa Paula en la Cofradía de Nuestra Señora del Rosario y Oración en el Huerto, dando por ello una alcancía de 70 reales y 22 libras de cera nueva, además de unas potencias de plata con piedras engastadas para el Cristo Crucificado, imagen que estaba en dicho convento y que pertenecía a la Cofradía ${ }^{125}$. Aunque no hayamos podido consultar el archivo de la Hermandad de Nuestra Señora de la Soledad, conocemos, a través de una publicación de Cañizares Japón, que en 1595 entraron como hermanas la abadesa y monjas del convento del Dulce Nombre de Jesús ${ }^{126}$.

No fueron estas las únicas en entrar en una hermandad, pues también lo hicieron las monjas del convento de Santa María de las Dueñas en la Cofradía de Nuestra Señora de la Concepción, del convento de Regina, el 4 de febrero de $1601^{127}$. Estas entradas continuaron el 17 de abril, cuando una monja del mismo cenobio dio por su entrada 20 reales, y el 29 de abril, cuando se recibieron dos dando para ello 40 reales $^{128}$. También entraron como cofradas en esta Hermandad las monjas del convento de Santa Clara, documentadas desde $1628^{129}$ cuando averiguaron y las de Santa Inés desde $1651^{130}$.

Por último tenemos a la carmelita Juana Bautista ${ }^{131}$, aunque no nos deja totalmente claro la documentación si era monja claustral o perteneciente a la Orden Tercera Carmelita, orden cuya potestad para agregar laicos a su Orden en forma de Tercera Orden recibió en $1452^{132}$, pues solo aparece como de la Orden del Carmen, entrando en 1553 en la Cofradía del Traspaso.

123. Fraga Iribarne 1993; Gestoso y Pérez 1984; Madoz 1986; Miura Andrades 1998; Morgado 2017; Ortiz de Zúñiga 1988; Pérez González 2005; Pérez del Prado 2000; Sánchez Gordillo 1983; Sánchez Herrero 1984; Rodríguez Liáñez 1986.

124. Mingorance Ruiz 2013, p. 579.

125. AGAS, Justicia, Hermandades, leg. 09797, exp. 1, f. 19r.

126. Cañizares Japón 2007, p. 56.

127. AHSL, Fondo Hermandad de la Concepción de Regina, 4. Mayordomía, Libro de cuentas, 1601-1745, f. 2v.

128. Ibidem, f. 5 r.

129. Ibid., f. 122r.

130. Ibid., s.f.

131. AHGP, Libro 41, Libro de asiento de hermanos, 1551-1654, s.f.

132. Pérez González 2005, p. 109. 


\subsubsection{Extranjeras}

Solamente hemos documentado una extranjera, entiéndase por extranjera las que no eran naturales de la Corona de Castilla. Nos referimos a Isabel Fernández, la portuguesa, quien entró en la Cofradía del Traspaso el 16 de marzo de $1604^{133}$.

\subsubsection{Nobleza y aristocracia}

De entre los pocos libros de entradas de hermanas conservados únicamente constatamos a una mujer perteneciente a la nobleza. Nos referimos a doña Andrea de Cisneros Castroviejo, Marquesa de Aguiar, quien entró el 19 de diciembre de 1689 en la Cofradía de Nuestra Señora de la O y Santa Brígida ${ }^{134}$. Doña Andrea de Cisneros Castroviejo Lodeña y Vargas, natural de Madrid, era la mujer de don José de Rivera Tamariz, I Marqués de Aguiar, por Real Despacho de 11 de septiembre de 1689, y veinticuatro de Sevilla ${ }^{135}$. No hemos podido hallar más datos sobre esta insigne mujer, salvo que murió el 1 de noviembre, festividad de Todos los Santos, de $1697^{136}$.

\section{LAS PROFESIONES DE LAS COFRADAS}

La mujer fue marginada tradicionalmente en el ámbito laboral, en el que su trabajo, muy presente en la economía del Antiguo Régimen, no parecía tener importancia (...) y era incluso ocultado por las fuentes documentales ${ }^{137}$. Ninguna de ellas pudo ostentar un cargo público, aunque sí pudieron transmitirlos, pues eran en su mayor parte una propiedad privada, mediante la venta de oficios. Dos casos documentamos con respecto a esta transmisión o ventas de cargos públicos. El primero de ellos data de 1661, año en el que don Pedro Caballero de Illescas, caballero de la Orden de Santiago, tenía un tributo de cantidad de tres mill ducados de bellón de prinçipal sobre los bienes de doña Ana María de Retana y Olalde. $Y$ entre ellos como bienes de la susodicha es el officio de alcalde maior de esta ciudad que yo uso $^{138}$, tributo que se pagaba a la Hermandad de la Vera Cruz.

Doña Ana María de Retana y Olalde era hija de Pedro de Retana Olalde (hijo de Rodrigo de Olalde y de Catalina Fernández de Retana) y de Luisa de Hervás Aviñón (hija de Jerónimo de Hervás y de Juana Vázquez de la Vega), los cuales fundaron mayorazgos en 1610 en sus hijas, Ana María y Josefa Gabriela de Retana

133. AHGP, Libro de asiento de hermanos, 1551-1654, f. 90r. Libro 46r. Sobre la población portuguesa en Sevilla González Espinosa 2015, 2016.

134. AHO, III. Registro de cofrades y cofradas, Asiento de hermanos, 1675-1718, f. 22r.

135. Alós 2009, p. 200; Atienza 1993, p. 140; Fernández-Mota de Cifuentes 1984, p. 15.

136. AHO, III. Registro de cofrades y cofradas, Asiento de hermanos, 1675-1718, f. 22r.

137. Soria Mesa 2003, p. 462.

138. AHVC, Libro 2, Libro de actas de cabildos, 1654-1668, f. 59r. Cabildo de 18 de septiembre de 1661 . 
Olalde, esposa de Juan de Henestrosa Cárdenas ${ }^{139}$. Esta se casó con Diego López de Chaves y fue madre de Garcí López de Chaves Herrera, señor de Villavieja y Pedraza, quien contrajo nupcias con María de Guzmán Ocampo Maldonado, III marquesa de Cardeñosa.

El segundo caso data de 1697, fecha en la que doña Bernarda Gutiérrez de Flandes, viuda de don Manuel Ramón Gómez, transmitió el oficio de fiscal de la Justicia y Rentas Reales de Sevilla a don Duarte de Sierra ${ }^{140}$. Esta misma vendió a la Hermandad de la Vera Cruz un censo de 30.000 reales de principal sobre este oficio, escritura que pasó ante Diego Francisco de Águila, escribano público, el 28 de octubre de $1697^{141}$.

No son muchos los datos que disponemos para conocer la profesión que tenían las cofradas, pues únicamente documentamos seis entradas en las que aparecen sus actividades. El grupo más numeroso lo conforman las criadas. A finales del siglo XV el modelo tradicional de servicio doméstico fue cambiando a un sistema de trabajo remunerado, en el que los criados negociaban los contratos con quienes los empleaban. Como resultado de ello, éstos pasaron a depender progresivamente de las condiciones del mercado para obtener nuevas posiciones o escalar en la jerarquía social ${ }^{142}$, naciendo una concepción del servicio doméstico basado en la producción y el beneficio debido a la creciente cultura del consumismo.

Este cambio de concepción fue particularmente significativo para las mujeres que fueron progresivamente sustituyendo a los hombres como criadas en las casas de importante nivel económico ${ }^{143}$. Documentando tres. De la primera de ellas ni siquiera se nos presenta el nombre, únicamente que fue la criada de Andrés Pinto ${ }^{144}$, quien entró en 1608 en la Hermandad de la Oración en el Huerto y Nuestra Señora del Rosario. El 4 de octubre de 1618 lo hizo en la Cofradía del Traspaso Ana Bautista ${ }^{145}$, criada de Bartolomé Díaz, y el 7 de abril de 1668 María Francis$\mathrm{ca}^{146}$, criada en casa del marqués de Villamanrique, en la Hermandad de las Tres Caídas y Nuestra Señora del Arco.

Un único caso documentamos de una gallinera, María de los Ángeles ${ }^{147}$, quien entró el 12 de abril de 1618 en la Cofradía del Traspaso. Al igual que una chocolatera, Magdalena López ${ }^{148}$, quien lo hizo el 21 de abril de 1666 en la Hermandad de Tres Caídas y Nuestra Señora del Arco, y una ollera, Teresa González, quien en 1593 tenía una alcancía de la Cofradía de Nuestra Señora del Rosario y Oración

139. Argáiz 1668, p. 368; Salazar y Castro 1696, p. 690.

140. AHVC, Libro 4, Libro de acuerdos, 1694-1715, f. 32r. Foliación propia. Cabildo de 27 de octubre de 1697.

141. AHVC, Caja 55, Censo sobre el oficio de fiscal de la Real Justicia, 1697.

142. Pérez González, Mingorance Ruiz 2017.

143. Ibidem.

144. AGAS, Justicia, Hermandades, leg. 09797, exp. 3, f. 13r.

145. AHGP, Libro 41, Libro de asiento de hermanos, 1551-1654, f. 90r.

146. AHTCSI, 2. Secretaría, 2.1.1.1. Libro de registros de hermanos, Libro de entradas de hermanos, 1636, f. 148r.

147. AHGP, Libro 41, Libro de asiento de hermanos, 1551-1654, f. 89r. Libro 41

148. AHTCSI, 2. Secretaría, 2.1.1.2. Libro de registro de hermanas, Libro de entradas de hermanas, 1663-1710, f. 7v. 
en el Huerto ${ }^{149}$. Sí encontramos más profesiones, pero estas, al no ser relativas a cofradas y hermanas, no las tratamos en este estudio.

Además de estos, cuyo oficio viene expresado con total claridad, tenemos otros dudosos. Ana de Prado ${ }^{150}$ y Sebastiana de los Ríos ${ }^{151}$ eran hermanas de las Tres Caídas y Nuestra Señora del Arco, entrando la primera en 1670 y la segunda en 1669. Ambas tenían tabernas, la segunda además una tienda. Ana de Prado la tenía en la collación de Santa Catalina y Sebastiana de los Ríos en la de San Bartolomé. Presumiblemente podríamos decir que sus oficios eran los de tabernera, pero sin poderlo afirmar con total certeza. En otros casos la duda es mayor, ya que únicamente se nos apunta que moraban en tiendas y tabernas, pero no sabemos si eran propietarias de estas, simples trabajadoras o solo las habitaban.

\section{MuJeres EN EL GOBIERNO DE LAS COFRADÍAS}

En una sociedad prioritariamente dominada por el hombre, las cofradías no eran una excepción. Aunque la profesora Pérez González documentara una priosta para el caso de Jerez de la Frontera en su estudio publicado en 2012 para la época bajomedieval ${ }^{152}$, no era lo normal. En todos los casos de cofradías documentadas entre los siglos XVI y XVII constatamos que las mujeres no tenían la obligación de ir a los cabildos, ni aunque estas quisieran ir podían ser admitidas ${ }^{153}$, mucho menos podían ejercer cargos de oficiales.

Pese a esta normativa extendida hemos podido documentar dos casos en los que sí ha habido mujeres en el gobierno cofrade, siendo algo extraordinario y muy poco usual. Aunque en el Libro de Reglas de la Cofradía del Dulce Nombre de Jesús se estableció que la mujer tenía que estar presente en el cabildo para leer su petición de entrada ${ }^{154}$, no podríamos considerarlo como uno de los aspectos que en este apartado estudiamos, pues su presencia creemos que era únicamente para constatar que dicha petición era recibida y leída.

El primero de los dos únicos, y extraordinarios, casos lo documentamos en 1679, cuando el 25 de junio los oficiales de la Cofradía de Nuestra Señora de los Ángeles, de los morenos, hicieron cabildo de elecciones ${ }^{155}$. En él no se eligieron

149. AGAS, Justicia, Hermandades, leg. 09797, exp. 1, f. 363v. Alcancías repartidas en la Cuaresma de 1593 .

150. AHTCSI, 2. Secretaría, 2.1.1.1. Libro de registros de hermanos, Libro de entradas de hermanos, 1636, f. 181r.

151. AHTCSI, 2. Secretaría, 2.1.1.2. Libro de registro de hermanas, Libro de entradas de hermanas, 1663-1710, f. 9v.

152. Pérez González 2012, p. 197.

153. AHT, Carpeta 1, Libro de reglas, 1544, f. 24v. Aprobación del provisor; AGAS, Justicia, Hermandades, leg. 09885, exp. 1, f. 83r. Capítulo XXII; AHO, I. Reglas y constituciones, Libro de reglas, 1566, f. 13v. Capítulo XVII; AHSL, Fondo Hermandad de la Concepción de Regina, Libro de reglas, 1549, f. 16r. Capítulo XII.

154. AHQA, Legajo C, Libro de reglas de la Hermandad del Dulce Nombre, 1572, f. 12v. Capítulo XIX.

155. AHN, Libro de actas de cabildos, 1675-1775, f. 16r. Cabildo de 25 de junio de 1679. 
oficiales varones, sino a una mayordoma y a una hermana mayor para que asistieran la capilla, acordándose elegir por hermana mayor a la señora Luisa, mujer del señor Juan Francisco, a la sazón diputado mayor, teniendo esta la facultad de elegir por ella misma una mayordoma a su satisfaçión, quieta, pasífica y apasible. Esta señora venía a sustituir a la antigua hermana mayor, la madre Gracia, quien había fallecido. No contamos con más noticias de elecciones de oficialas, salvo que en 1700 seguía existiendo una hermana mayor, cuando se documenta dando de limosna un escudo para el sermón del Domingo de Ramos de dicho año ${ }^{156}$.

Este cabildo de elección de oficialas fue publicado por Moreno, quien sostenía la hipótesis de que estas funciones eran las mismas que las que tuvieron con el tiempo las camareras actuales: hacerse cargo del lavado y limpieza de las ropas de las imágenes y de las destinadas al culto y cooperar con el prioste en el cuidado de la capilla ${ }^{157}$. También daba la posibilidad de que hubiera una división de responsabilidades dentro de la Hermandad, respecto al colectivo de mujeres, paralelas a las de los hombres. Así, por ejemplo, la mayordoma podría ocuparse de la organización de las formas de obtener ingresos por parte de las cofradas, y la hermana mayor la de plantear iniciativas y ser la cabeza visible de estas para la interlocución con la mesa de la Cofradía ${ }^{158}$.

En toda la Historia de las cofradías de Sevilla solo hemos podido documentar un caso, al menos hasta la fecha, de un cabildo compuesto únicamente por mujeres, siendo un hecho prácticamente único. Su fecha fue el 5 de marzo de 1690 en el cual las cofradas de la Hermandad de Nuestra Señora del Patrocinio, sita en su capilla de Nuestra Señora del Patrocinio y Santo Cristo de la Expiración, en Triana, extramuros de Sevilla, se reunieron en cabildo para hacer elecciones ${ }^{159}$. En él se congregaron 38 mujeres.

De estas mujeres tenemos más noticias, pocas y reducidas en realidad, pues nos ha llegado un libro de hermanas fechado el 6 de abril de $1680^{160}$. A través de este libro podemos ver la fecha de entrada de estas cofradas, que reflejamos en la siguiente Tabla:

Tabla 5. Cofradas del cabildo de elecciones del 5 de marzo de 1690 de la Hermandad de la Expiración y Nuestra Señora del Patrocinio.

\begin{tabular}{|l|c|}
\hline \multicolumn{1}{|c|}{ NOMBRE } & ENTRADA \\
\hline Ana Barrantes $^{1}$ & 16 de junio de 1680 \\
\hline Ana de Armante & No consta \\
\hline Ana de Campos & No consta \\
\hline
\end{tabular}

156. AHN, Libro de mayordomía, 1675, f. 45v.

157. Moreno 1997, p. 132.

158. Ibidem.

159. AHCH, 1. Gobierno, 1.1.2.1. Actas de cabildos, Libro de actas de cabildos, 1681-1716, Caja 2, Libro 4, f. 7r. Cabildo de 5 de marzo de 1690.

160. AHCH, 2. Secretaría, 2.1.2.1. Libro registro de hermanos, Libro de hermanos, 1680-1722, Caja 18, Libro 23. 


\begin{tabular}{|c|c|}
\hline NOMBRE & ENTRADA \\
\hline Ana de Morera & 6 de noviembre de 1689 \\
\hline Ana Francisca del Ángel & 1690 \\
\hline Ana Rodríguez & Averiguó en 1689 \\
\hline Antonia del Ángel & 1690 \\
\hline Beatriz Josefa & Averiguó en 1689 \\
\hline Brígida Benítez & Averiguó en 1689 \\
\hline Catalina Corales & Averiguó en 1689 \\
\hline Catalina Guillena & 1690 \\
\hline Catalina Romera & 1690 \\
\hline Doña Francisca, mujer de Manuel Vázquez ${ }^{2}$ & Averiguó en 1689 \\
\hline Francisca de los Reyes & 1689 \\
\hline Francisca del Ángel & 1689 \\
\hline Inés Rodríguez ${ }^{3}$ & 22 de abril de 1680 \\
\hline Inés Vicente & Averiguó en 1689 \\
\hline Isabel del Ángel & 1690 \\
\hline Doña Isabel de Girola & 1689 \\
\hline Josefa María Morsela & Averiguó en 1689 \\
\hline Juana de Valladares & 1690 \\
\hline Juana del Río & No consta \\
\hline Juana Vázquez & Averiguó en 1689 \\
\hline Leonor Pérez & 1680 \\
\hline Luisa Benítez & 1690 \\
\hline Luisa Gómez & 1690 \\
\hline Magdalena Benítez & 1690 \\
\hline Doña Manuela & 1690 \\
\hline María de Santiago & No consta \\
\hline María del Ángel $^{4}$ & No consta \\
\hline María del Río & 1689 \\
\hline María Jiménez & 22 de abril de 1680 \\
\hline María Pantoja & 1690 \\
\hline María Pérez del Ángel & 1690 \\
\hline María Rosa & 1689 \\
\hline María Salgada & 1690 \\
\hline Miguelasa Francisca & No consta \\
\hline Doña Teresa Morsela & 1689 \\
\hline
\end{tabular}

1. También documentamos a una Ana Barrantes, la vieja, quien entró en 1689. AHCH, 2. Secretaría, 2.1.2.1. Libro registro de hermanos, Libro de hermanos, 1680-1722, Caja 18, Libro 23, f. 47r.

2. Documentamos a una tal Francisca Lara, mujer de Pedro Vázquez, quien averiguó en 1689 que podría ser esta misma doña Francisca.

3. Era mujer de Juan del Valle.

4. Se documenta a una María del Ángel, hija de Juana Bautista del Ángel, quien entró en 1699, pero evidentemente no son la misma persona. $\mathrm{AHCH}, 2$. Secretaría, 2.1.2.1. Libro registro de hermanos, Libro de hermanos, 1680-1722, Caja 18, Libro 23, f. 102r. 
De dicha acta podemos sacar varias conclusiones. En primer lugar nos llama la atención que, con seguridad, no fue la primera vez que las hermanas se reunieron en cabildo, pues cuentan que fueron con campana tallida como lo han de uso y costumbre $^{161}$. Aunque el uso y costumbre es una fórmula muy recurrente en todas las actas de cabildo estudiadas, creemos que alude a otras reuniones de estas mujeres que, al no saber escribir como aludieron, quizás no pudieron ser reflejadas por escrito o, simplemente, no ha llegado hasta nosotros esa documentación. Sea como fuere, este cabildo estuvo compuesto por mujeres para haser y deshaser lo que megor conbenga para dicha Capilla y nombrar a priostas, mayordomas y las demás ofisialas, saliendo electas las siguientes:

- Priostas: Ana de Morera y doña Francisca, la mujer de Andrés Núñez.

- Mayordomas: Inés Rodríguez y doña Francisca, mujer de Manuel Vázquez.

- Fiscalas: María de Santiago y doña Josefa Marcela.

- Escribana: doña Isabel de Girola.

El cometido de estas oficialas era el de asistir a la capilla. El acta de este cabildo fue escrito por Andrés González, escribano de la Cofradía, pues las mujeres no firmaron por no saber ${ }^{162}$. Este acuerdo fue transcrito y publicado por Macías Míguez en un libro que ha pasado desapercibido en la historiografía cofrade de Sevilla $^{163}$. Su autor, tratando el origen de la actual Hermandad del Cachorro, pensó en una posible fundación de la Cofradía de la Expiración y Nuestra Señora del Patrocinio por parte de las mujeres, hipótesis que, en nuestra opinión, no se sostiene.

Como podemos comprobar, ambos historiadores, Moreno y Macías Míguez, tratan estos dos ejemplos de mujeres en el poder más como casos normales, comunes y anecdóticos que como momentos únicos y extraordinarios, pues no existen, de momento, otros que nos permitan hablar de una globalidad y no de un unicum, no dándole la importancia que merece.

Aunque no pertenece a la Junta de Gobierno, hay un cargo que sí está muy relacionado con los oficiales: las camareras, que no recibían tal denominación en la época estudiada. Durante los siglos XVI y XVII el cargo de vestir las imágenes había recaído tanto en hombres como en mujeres. Para el siglo XVI documentamos en la Cofradía de Nuestra Señora del Rosario y Oración en el Huerto a María de Mar ${ }^{164}$, que en 1588 tenía a su cargo el vestir la talla de la Virgen del Rosario, a la cual los alcaldes, en presencia del escribano, dieron un rosario de corales gruesos con ocho extremos de oro donado por María Díaz, cofrada de la Hermandad, y a la dicha María de Mar se hizo de ellos y los prometió de los tener en su poder y de los dar cada (vez) que los dichos alcaldes los pidieren o otros que fueren de aquí adelante, firmándolo ella misma. Nuevamente, recibió en 1589 otro rosario que

161. AHCH, 1. Gobierno, 1.1.2.1. Actas de cabildos, Libro de actas de cabildos, 1681-1716, Caja 2, Libro 4, f. 7r. Cabildo de 5 de marzo de 1690.

162. Ibidem, f. $7 \mathrm{v}$.

163. Macías Míguez 1982, pp. 48-52.

164. AGAS, Justicia, Hermandades, leg. 09797, exp. 1, s.f. Cabildo de 8 de diciembre de 1588 . 
dio otra mujer devota, desconociéndose si era hermana o no ${ }^{165}$, siendo ese mismo la que vistió a la Virgen para la procesión del Corpus Christi ${ }^{166}$.

Por último, para 1659, 1661 y 1662 documentamos a doña Francisca Jerónima de los Ángeles, encargada de vestir a Nuestra Señora de la O, de la Cofradía de su misma advocación, recibiendo por ello un salario de 50 reales, cuya carta de pago fue firmada por ella ${ }^{167}$. Por lo tanto, vemos que este cargo, honorífico por lo general, estaba limitado al mantenimiento de los vestidos y alhajas de las imágenes y, quizás, a la limpieza de las capillas ${ }^{168}$.

\section{CONCLUSIONES}

De este artículo podemos sacar varias conclusiones al respecto. Lo primero es relativo al volumen documental. Solo se conservan cuatro libros de entradas de mujeres frente a los catorce de hombres que también hemos estudiado para nuestra tesis doctoral, lo que no equivale ni a la tercera parte de estos últimos. Es un hecho histórico que la documentación ha llegado a nuestros días de forma parcial y se ha perdido mucha a lo largo de los tiempos por avatares históricos y naturales. Pero esto parece indicar, además, que se tuvo un especial interés y cuidado en guardar, custodiar y transmitir los asientos de los hermanos, quienes eran los que gobernaban en las cofradías, pero no tanto los de las mujeres, que hasta relativamente poco no pudieron.

Lo segundo que nos llama la atención, quizás la conclusión principal de todas, es que la mujer durante estos siglos tuvo dentro de las cofradías penitenciales un papel medianamente igualitario con respecto al hombre, o podríamos decir que era casi equitativo. Es decir, hubo algunas facetas o aspectos, pocos en verdad, dentro de la vida de estas corporaciones en los que la mujer estuvo vetada y excluida, salvo casos excepcionales. Pero, por el contrario, en otros tuvo los mismos privilegios y los mismos deberes que el varón.

Comenzando por el ingreso, comprobamos que el procedimiento era exactamente el mismo que se requería para el hombre, compartiendo unas calidades comunes, si bien la mujer accedió a la cofradía principalmente, que no exclusivamente, mediante la mano del varón, ya fuera como marido, como padre o como hermano. Las cofradas, al igual que los hombres, tenían que pagar una cuota pero esta era, en muchos casos, superior, a veces incluso el doble, que la de los hermanos varones. Esto se entiende que a menor responsabilidad, más alto la cuota. Las mujeres apenas tenían responsabilidades en las cofradías, en el sentido de que no podían ir a cabildo, ni tener oficios, ni tampoco tenían obligación de asistir a las misas en algunas hermandades.

165. Ibidem, s.f. Cabildo de 1 de enero de 1589.

166. Ibid., f. 11r. Cabildo de 28 de mayo de 1589.

167. AHO, VI. Clavería y Mayordomía, Cuentas desde 1614 a 1686, f. 327r, 338v y 344r. Cuentas de 1659,1561 y 1562 , respectivamente.

168. Sánchez Rodríguez 2003, p. 214. 
Mediante la comparación de las cuotas de hermanas, tanto de luz como de sangre, y de las cofradas podemos observar tres tipos de pagas. Una en la que la entrada era equitativa tanto a hombres (de luz principalmente) como mujeres (Amor, Cinco Llagas, Coronación y Santa Verónica, Dulce Nombre de María, Expiración, Nuestra Señora de las Angustias y Tres Caídas y Nuestra Señora del Arco). Otra en la que la cuota para la mujer era superior a la del hombre (Dulce Nombre de Jesús, Nuestra Señora de la Concepción y Vera Cruz), mientras que en otras era el doble (Buen Viaje y Esperanza y Sentencia). El tercer grupo, y menos común, corresponde con aquellas donde la cuota era menor que la del varón, entiéndase menor que la del hermano de luz que era, de los hombres, el que más pagaba (Columnas y Azotes, Expiración y Nuestra Señora del Patrocinio, San Juan Evangelista, Santo Sudario y Traspaso).

En cuanto a la forma de entrada de la mujer, podemos apreciar que esta podía acceder a las cofradías por sí mismas, ya fuera por devoción o por cualquier otro motivo personal, o bien mediante el marido. En este último caso casi siempre tenían que pagar la mitad de la cuota que aquellas mujeres que entraban por ellas mismas.

Ya mencionamos que la forma más común de acceso por parte de las mujeres era mediante su relación con un hombre. Dentro de esta, la forma más habitual era por mano del marido, que no es ninguna novedad al respecto, pero también fue importante el de las hijas, muchas de ellas mediante la herencia de la candela de sus padres. Las hijas primogénitas, al igual que los hijos, tenían el derecho de heredar la vela del padre difunto, aunque muchas hermandades prefirieron al varón, pese a que fuera menor. Es decir, la igualdad jurídica de las hijas primogénitas estaba, pero no tanto en la práctica.

De los grupos de mujeres estudiados nos han interesado principalmente tres: las doncellas, las viudas y las mujeres religiosas (tanto monjas como laicas). Las doncellas son importantes estudiarlas porque ellas fueron principalmente las que pudieron acceder a las dotes que muchas cofradías y hermandades daban, bien para su casamiento o bien para entrar en religión.

El grupo más interesante son las mujeres religiosas. Dentro de este encontramos beatas y monjas, dos caminos a través de los cuales la mujer pudo expresar su religiosidad pero muy diferentes uno de otro. Mientras que las primeras tuvieron un contacto más directo con las cofradías, conociéndose sus nombres, las segundas, las monjas, fueron más aisladas. Esto se debe a la vida de clausura que llevaban. Mientras que los frailes tenían una vida más relacionada con los laicos, las monjas llevaban una vida muy recogida en sus conventos, con pocos tratos con las personas del exterior, por lo que fueron muy pocas, casos contados, las monjas que accedieron a las cofradías. Cuando lo hacían, entraron en grupos como colectivos y no como individuos, desconociéndose en muchos casos los nombres por ese colectivismo.

Atendiendo a los trabajos de estas cofradas apreciamos, aunque son pocos los detalles, que sus labores estaban relacionados con el sector terciario, especialmen- 
te el de servidumbre (criadas) y en el de servicios, sobre todo los relacionados con la comercialización de la alimentación.

Sobre el gobierno y su acceso a los oficios o cargos partimos de la base de que la mujer no podía ejercer ningún oficio en las cofradías penitenciales sevillanas, tampoco podían reunirse en cabildo, pero esto no fue del todo cierto. La verdad es que sí pudieron, pudieron tener cargos y reunirse en juntas, pero estos casos fueron raros y creemos que más honoríficos que prácticos. También tuvieron una continuidad en el tiempo, es decir, no fueron casos que se produjeron una única vez y contaron con una amplia asistencia, al menos en el caso del cabildo con un total de 38 cofradas, una cifra bastante alta si la comparamos con muchos cabildos de hombres de otras cofradías. También rechazamos por completo la hipótesis de la formación de una cofradía exclusivamente compuesta por mujeres, cofradía que luego se uniría a otra para formar la de la Expiración y Nuestra Señora del Patrocinio. En definitiva, no estuvo prohibido el gobierno a las cofradas pero tampoco fue accesible del todo a todas las mujeres, solamente a casos extraordinarios.

Desgraciadamente no podemos sacar más conclusiones sobre la vida de las cofradas en el seno de las hermandades debido a la ausencia de estas en la documentación, bien porque no se han conservado o bien porque aparecen en el anonimato. Para ello habrá que esperar nuevas investigaciones en donde se empleen distintas fuentes documentales o archivos (como por ejemplo el Histórico Provincial, el Archivo Municipal o, en menor medida, el Archivo Histórico Nacional), que esperamos poder realizar.

\section{BIBLIOGRAFÍA}

Alós, Fernando de (2009), Los Brizuela: Condes de Fuerubia y familias enlazadas, Madrid.

Arboleda Goldaracena, Juan Carlos; Pérez González, Silvia María (2016), “Mujer y religiosidad. La participación femenina en las cofradías sevillanas de los siglos XIV al XVI", Estudios sobre patrimonio, cultura y ciencias medievales, 18, pp. 107-130.

Argáiz, fray Gregorio de (1668), Corona real de España por España fundada en el credito de los muertos y vida de San Hyeroteo obispo de Atenas y Segouia, Madrid.

Arias de Saavedra Alías, Inmaculada; López-Guadalupe Muñoz, Miguel Luis (2017), "Las cofradías españolas en la Edad Moderna desde una óptica social: Tres décadas de avance historiográfico", Cuadernos de estudios del siglo XVIII, 27, pp. 11-50.

Atienza, Julio de (1993), La obra de Julio de Atienza y Navajas, Barón de Cobos de Belchite y Marqués del Vado Glorioso en "Hidalguía", Madrid.

Avellá Cháfer, Francisco (1982), "Beatas y beaterios en la ciudad y arzobispado de Sevilla", Archivo Hispalense, 198, pp. 99-132. 
Calderón Berrocal, María del Carmen (2002), “XXV. Hermandad y Cofradía de la Preciosa Sangre de Cristo. Sevilla, 1581”, Sánchez Herrero, José (ed.); Pérez González, Silvia María (coord.), CXIX reglas de hermandades y cofradías andaluzas: siglos XIV, XV y XVI, Huelva.

Cañizares Japón, Ramón (2007), La Hermandad de la Soledad: devoción, nobleza e identidad en Sevilla (1549-2006), Sevilla.

Cañizares Japón, Ramón (2014), Las antiguas reglas de la Hermandad de la Soledad de Sevilla, Sevilla.

Cañizares Japón, Ramón (2017), “II. Cofradía del Traspaso y Soledad de Nuestra Señora (Sevilla, 1555-1557, 1569, 1592)”, Pérez González, Silvia María (dir.); Arboleda Goldaracena, Juan Carlos (coord.), CXXII reglas de hermandades y cofradias andaluzas: siglos XVI y XVII, Huelva.

Casquero Fernández, José-Andrés (1997), "La religiosidad de las mujeres: las cofradías de Santa Águeda en la diócesis de Zamora, siglos XVII-XIX", Campos Fernández de Sevilla, Francisco Javier (dir.), Religiosidad popular en España: actas del simposium 1/4-IX-1997, El Escorial, vol. I, pp. 57-80.

Domínguez Ortiz, Antonio (1986), Historia de Sevilla. La Sevilla del siglo XVII, Sevilla.

Echániz Martínez, Berta (2012), "Una aproximación a la espiritualidad femenina en el Alicante de principios del siglo XVII", Feminismo/s, 20, pp. 275-295.

Fernández-Mota de Cifuentes, María Teresa (1984), Relación de títulos nobiliarios vacantes y principales documentos que contiene cada expediente que, de los mismos, se conserva en el Archivo del Ministerio de Justicia, Madrid.

Fraga Iribarne, María Luisa (1993), Conventos femeninos desaparecidos: arquitectura religiosa perdida durante el siglo XIX en Sevilla, Sevilla.

García de la Concha Delgado, Federico (2002b), "XXVII. Cofradía del Santísimo Sudario de Nuestro Señor Jesucristo y Madre de Dios de la Palma. Sevilla, 1593”, Sánchez Herrero, José (ed.); Pérez González, Silvia María (coord.), CXIX reglas de hermandades y cofradías andaluzas: siglos XIV, XV y XVI, Huelva.

García de la Concha Delgado, Federico (2002c), "XXXII. Hermandad y Cofradía de Nuestra Señora del Buen Viaje. Sevilla, 1596”, Sánchez Herrero, José (ed.); Pérez González, Silvia María (coord.), CXIX reglas de hermandades y cofradias andaluzas: siglos XIV, XV y XVI, Huelva.

García Herrero, María del Carmen (2018), Los jóvenes en la Baja Edad Media: estudios y testimonios, Zaragoza.

Gestoso y Pérez, José (1984), Sevilla monumental y artística, Sevilla.

González Espinosa, Ignacio (2015), "Portugueses en Sevilla: sus oficios y profesiones durante el reinado de Felipe III", Iglesias Rodríguez, Juan José; Pérez García, Rafael M.; Fernández Chaces, Manuel Francisco (coords.), Comercio y cultura en la Edad Moderna: actas de la XIII reunión científica de la fundación de Historia Moderna, Sevilla, vol. II, pp. 731-741.

González Espinosa, Ignacio (2016), "Pautas de movilidad de las familias portuguesas a Sevilla (1600-1615)”, García Fernández, Máximo (coord.), Familia, 
cultura material y formas de poder en la España moderna. III Encuentro de jóvenes investigadores en Historia Moderna, Valladolid 2 y 3 de julio de 2015, Madrid, pp. 131-140.

Granado Hermosín, David (2014), Iglesia y arte: estudio histórico-artístico del patrimonio religioso de Alcalá de Guadaíra en el siglo XVII, Sevilla. Trabajo de Fin de Máster.

Granado Hermosín, David (2016), “La devoción de los laicos en la Alcalá de Guadaíra del siglo XVII: cofradías, fiestas, prácticas y conductas”, Peinado Guzmán, José Antonio; Rodríguez Miranda, María del Amor (coords.), Meditaciones en torno a la devoción popular, Córdoba, pp. 194-215.

Granado Hermosín, David (2017), "La Hermandad de las Tres Caídas de San Isidoro durante el siglo XVII. Una introducción”, Granado Hermosín, David; García Granado, José María (coords.), III Centenario de Ntra. Sra. de Loreto. La Cofradía de las Tres Caídas de San Isidoro en el siglo XVIII, Sevilla, pp. 57-82.

Hermandad del Dulce Nombre (2009), Reglas de la Pontificia, Fervorosa, Ilustre y Antigua Hermandad y Cofradía de Nazarenos de Nuestro Padre Jesús ante Anás, Santo Cristo del Mayor Dolor, María Santísima del Dulce Nombre y San Juan Evangelista, Sevilla. Edición facsímil.

Herrera García, Antonio (2002), "XXIII. Hermandad y Cofradía de Nuestra Señora de las Aguas y Santa Expiración de Jesucristo. Sevilla, 1575", Sánchez Herrero, José (ed.); Pérez González, Silvia María (coord.), CXIX reglas de hermandades y cofradias andaluzas: siglos XIV, XV y XVI, Huelva.

Jiménez Sampedro, Rafael (2005), "Regla de la Hermandad de las Sagradas Tres Humillaciones de Cristo Redentor y Madre de Dios del Arco, año 1648", Boletín de las cofradias de Sevilla, 562, pp. 877-881.

León, Fray Luis de (2005), La perfecta casada, Palencia.

López-Guadalupe Muñoz, Miguel Luis (1992), Contrarreforma y cofradias en Granada: aproximación a la historia de las cofradias y hermandades de la ciudad de Granada durante los siglos XVII y XVIII, Granada.

López-Guadalupe Muñoz, Miguel Luis (1995), "Las cofradías de penitencia de Granada en la Edad Moderna", Gazeta de antropología, 11.

López-Guadalupe Muñoz, Miguel Luis (2016), "Cofradías y devociones populares en el convento de Santa Cruz la Real de Granada", Revista de humanidades, 27.

López-Guadalupe Muñoz, Miguel Luis; Arias de Saavedra Alías, Inmaculada (2000), "Las cofradías y su dimensión social en la España del Antiguo Régimen”, Cuadernos de historia moderna, 25, pp. 189-232.

López-Guadalupe Muñoz, Miguel Luis; Castaño Jiménez, María; Díaz Sánchez, Juan Antonio (2014), "La religiosidad y piedad popular en Granada, Baza y Huéscar. Una forma de evangelización tras la incorporación del reino de Granada a la Corona de Castilla (SS. XV y XVI)”, Péndulo. Papeles de Bastitania, 15, pp. 233-252. 
Macías Míguez, Manuel (1982), Antecedentes históricos de la Pontificia, Real e Ilustre Hermandad y Cofradía de Nazarenos del Santísimo Cristo de la Expiración y María Santísima del Patrocinio, Sevilla.

Madoz, Pascual (1986), Diccionario geográfico-estadístico-histórico de Andalucía. Sevilla, Valladolid.

Mingorance Ruiz, José Antonio (2013), Los extranjeros en Jerez de la Frontera a fines de la Edad Media, Sevilla. Tesis doctoral dirigida por los doctores Pérez González y Miura Andrades.

Mira Caballos, Esteban (2004), Pontificia y Real Hermandad y Cofradia de Nazarenos de Nuestro Padre Jesús del Gran Poder y María Santísima del Mayor Dolor y Traspaso: sus reglas de 1570, Sevilla.

Miura Andrades, José María (1989), “Algunas notas sobre las beatas andaluzas", Muñoz Fernández, Ángela (ed.), Las mujeres en el cristianismo medieval: imágenes teóricas y cauces de actuación religiosa, Madrid, pp. 289-302.

Miura Andrades, José María (1991), "Formas de vida religiosa femenina en la Andalucía medieval: emparedadas y beatas", Muñoz Fernández, Ángela; Graña, María del Mar, Religiosidad femenina: expectativas y realidades (ss. VIIIXVIII), Madrid, pp. 139-164.

Miura Andrades, José María (1998), Frailes, monjas y conventos. Las Órdenes Mendicantes y la sociedad sevillana bajomedieval, Sevilla, 1998.

Moreno, Isidoro (1997), La Antigua Hermandad de los Negros de Sevilla: etnicidad, poder y sociedad en 600 años de Historia, Sevilla.

Muñoz Fernández, Ángela (1990), "Parentesco artificial/parentesco natural en la vertebración social de las cofradías devocionales. Dos ejemplos madrileños de los siglos XV y XVI", Sánchez Herrero, José (dir.), Guía de los archivos de las cofradías de Semana Santa de Sevilla. Otros estudios, Madrid, pp. 369-391.

Muñoz Fernández, Ángela (1991), "Las mujeres en los ámbitos institucionales de la religiosidad laica: las cofradías devocionales castellanas (ss. XV-XVI)", Muñoz Fernández, Ángela; Graña, María del Mar, Religiosidad femenina: expectativas y realidades (ss. VIII-XVIII), Madrid, pp. 93-114.

Muñoz Fernández, Ángela (1994), Beatas y santas neocastellanas: ambivalencias de la religión y políticas correctoras del poder (sS. XIV-XVI), Madrid.

Morgado, Alonso (2017), Historia de Sevilla, Sevilla.

Ortiz de Zúñiga, Diego (1988), Anales eclesiásticos y seculares de la muy noble y muy leal ciudad de Sevilla, metrópoli de Andalucía, Sevilla.

Pérez González, Silvia María (2005), La mujer en la Sevilla de finales de la Edad Media: solteras, casadas y vírgenes consagradas, Sevilla.

Pérez González, Silvia María (2010), "Mujeres liberadas de la tutela masculina: de solteras y viudas a fines de la Edad Media", Cuadernos Kóre, 2, pp. 31-54.

Pérez González, Silvia María (2012), "Mujeres y cofradías en la Andalucía de finales de la Edad Media”, Historia. Instituciones. Documentos, 39, pp. 185211.

Pérez González, Silvia María; Mingorance Ruiz, José Antonio (2017), “Las mujeres de las colonias de extranjeros y su participación en la economía urbana a 
fines de la Edad Media: el Caso de Jerez de la Frontera”, Journal of Medieval Iberian Studies.

Pérez del Prado, Mercedes (2000), La iglesia mínima: el espacio en los templos de las clausuras conventuales sevillanas, Sevilla.

Pons Fuster, Francisco (1991), "Mujeres y espiritualidad: las Beatas Valencianas del Siglo XVII", Revista de historia moderna: Anales de la Universidad de Alicante, 10, pp. 71-96.

Poska, Allyson M.; Lehfeldt, Elizabeth A. (2002), "Las mujeres y la Iglesia en la España de la Edad Moderna", Dinan, Susan E.; Meyers, Debra (eds.), Mujeres y religión en el Viejo y el Nuevo Mundo, Madrid, pp. 37-63.

Río Barredo, María José del (2005), "Cofrades y vecinos: los sonidos particulares del Madrid barroco”, Marín López, Miguel Ángel; Bombi, Andrea; Carreras López, Juan José (coords.), Música y cultura urbana en la Edad Moderna, Valencia, pp. 255-278.

Rodríguez Liáñez, Laureano (1986), Real Monasterio de Santa Inés de Sevilla: colección diplomática y estudio histórico, Sevilla. Tesis Doctoral.

Salazar y Castro, Luis de (1696), Historia Genealógica de la Casa de Lara, justificada con instrumentos, y escritores de inviolable fe, Madrid.

Sánchez Gordillo, Alonso (1983), Religiosas estaciones que frecuenta la religiosidad sevillana, Sevilla.

Sánchez Herrero, José (1984), "Monjes y frailes. Religiosos y religiosas en Andalucía durante la Baja Edad Media", Actas del III coloquio de historia medieval andaluza: la sociedad medieval andaluza, grupos no privilegiados, Jaén, pp. 405-457.

Sánchez Herrero, José (1995), “La dotación de doncellas en la Cofradía y Hermandad de la Santa Vera Cruz de Sevilla, 1595-1832”, Sánchez Herrero, José (dir.), Las cofradias de la Santa Vera Cruz: actas del I Congreso Internacional de cofradias de la Santa Vera Cruz, Sevilla, pp. 69-125.

Sánchez Herrero, José (1997), "La acción benéfica de las cofradías durante los siglos XIV al XVII: la redención de cautivos y la dotación de doncellas para el matrimonio", Campos y Fernández de Sevilla, Francisco Javier, Religiosidad popular en España: actas del Simposium 1/4-IX-1997, El Escorial, vol. I, pp. 163-192.

Sánchez Herrero, José (2002), "V. Hermandad y Cofradía de la Santa Vera Cruz y Sangre de Jesucristo. Sevilla, 1538, 1631”, Sánchez Herrero, José (ed.); Pérez González, Silvia María (coord.), CXIX reglas de hermandades y cofradías andaluzas: siglos XIV, XV y XVI, Huelva.

Sánchez de Madariaga, Elena (1997), Cofradías y sociabilidad en el Madrid del Antiguo Régimen, Madrid.

Sánchez de Madariaga, Elena (1999), “Cultura religiosa y sociedad: Las cofradías de laicos", Historia social, 35, pp. 23-42.

Sánchez de Madariaga, Elena (2001), "Las cofradías en el Madrid Moderno", Pinto Crespo, Virgilio (coord.), Madrid, Atlas histórico de la ciudad siglos IX$X I X$, Madrid, pp. 350-357. 
Sánchez de Madariaga, Elena (2014), "Caridad, devoción e identidad de origen: las cofradías de naturales y nacionales en el Madrid de la Edad Moderna", Álvarez Gila, Óscar; Angulo Morales, Alberto; Ramos Martínez, Jon Ander (coords.), Localización: Devoción, paisanaje e identidad: las cofradías y congregaciones de naturales en España y en América (siglos XVI-XIX), Bilbao, pp. 17-32.

Sánchez Rodríguez, Paloma (2003), Mujeres y cofradías en Málaga, Málaga.

Segura Graiño, Cristina (1991), "Fuentes para hacer una historia de la religiosidad de las mujeres", Muñoz Fernández, Ángela; Graña, María del Mar, Religiosidad femenina: expectativas y realidades (ss. VIII-XVIII), Madrid, pp. 11-20.

Soria Mesa, Enrique (2003), "La sociedad en los siglos XVI y XVII”, García Cárcel, Ricardo (coord.), Historia de España: siglos XVI y XVII. La España de los Austrias, Madrid, 2003, pp. 433-466.

Vigil, Mariló (1986), La Vida de las mujeres en los siglos XVI y XVII, Madrid. 